\title{
Highly Enantio- and Diastereoselective One-Pot Synthesis of Acyclic Epoxy Alcohols and Allylic Epoxy Alcohols
}

\author{
Ann Rowley Kelly, Alice E. Lurain, and Patrick J. Walsh* \\ Contribution from the P. Roy and Diana T. Vagelos Laboratories, Department of Chemistry, \\ University of Pennsylvania, 231 South $34^{\text {th }}$ Street, Philadelphia, PA 19104-6323 \\ Email: pwalsh@sas.upenn.edu
}

\section{Supporting Information}

General Methods

Procedures and Characterization

${ }^{1} \mathrm{H}$ and ${ }^{13} \mathrm{C}\left\{{ }^{1} \mathrm{H}\right\}$ NMR Spectra

References 
General Methods. All reactions were carried out under a nitrogen atmosphere with oven-dried glassware. The progress of all reactions was monitored by thin-layer chromatography to ensure the reactions had reached completion. All manipulations involving dialkylzinc reagents were carried out using an inert atmosphere in a Vacuum Atmosphere drybox with an attached MO-40 Dritrain or by using standard Schlenk or vacuum line techniques. Dichloromethane and hexanes were dried through alumina columns. All aldehydes were distilled prior to use and stored under $\mathrm{N}_{2}$. Unless otherwise specified, all chemicals were obtained from Acros, Aldrich, or GFS Chemicals, and all solvents were purchased from Fischer Scientific. The ${ }^{1} \mathrm{H}$ NMR and ${ }^{13} \mathrm{C}\left\{{ }^{1} \mathrm{H}\right\} \mathrm{NMR}$ spectra were obtained on a Bruker AM-500 Fourier transform NMR spectrometer at 500 and $125 \mathrm{MHz}$, respectively. Chemical shifts are reported in units of parts per million downfield from tetramethylsilane, and all coupling constants are reported in Hertz. The infrared spectra were obtained using a Perkin-Elmer 1600 series spectrometer. Thinlayer chromatography was performed on Whatman precoated silica gel 60 F-254 plates and visualized by ultra-violet light or by staining with cerric ammonium molybdate stain. Silica gel (230-400 mesh, Silicycle) was used for air-flashed chromatography. Analysis of enantiomeric excess was performed using a Hewlett-Packard 1100 Series HPLC and a Chiralcel OD-H column or by chiral capillary gas chromatography on a Hewlett-Packard 6890 GC with a Beta-DEX column. Absolute configuration was determined by comparison of optical rotation to literature data for known compounds. 


\section{Compounds from Table 2.}

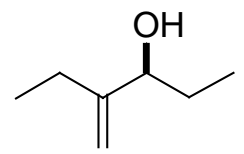

(Table 2, entry 1) (S)-2-Ethyl-pent-1-en-3-ol. General Procedure A. A $10 \mathrm{~mL}$ Schlenk flask was charged with (-)-MIB (1.9 mg, $0.008 \mathrm{mmol})$ and $1 \mathrm{~mL}$ hexanes and cooled to $0{ }^{\circ} \mathrm{C}$. A hexanes solution of $\mathrm{Et}_{2} \mathrm{Zn}(0.2 \mathrm{~mL}, 2.0 \mathrm{M})$ was added, followed by addition of 2-ethylpropenal $(16.8 \mathrm{mg}, 0.20 \mathrm{mmol})$ dropwise. The reaction was stirred at $0{ }^{\circ} \mathrm{C}$ for $8 \mathrm{~h}$ and quenched with a saturated solution of aq $\mathrm{NH}_{4} \mathrm{Cl}$. The organic and aqueous layers were separated, and the aqueous layer was extracted with hexanes $(3 \times 10 \mathrm{~mL})$. The combined organic layers were then washed with brine and $\mathrm{H}_{2} \mathrm{O}$ and dried over $\mathrm{MgSO}_{4}$. The filtrate was concentrated in vacuo and the residue was chromatographed on silica (20\% ethyl acetate in hexanes) to afford the title compound as a colorless oil in $80 \%$ yield $(45.7 \mathrm{mg}, 0.20 \mathrm{mmol}) .{ }^{1} \mathrm{H}$ NMR and ${ }^{13} \mathrm{C}\left\{{ }^{1} \mathrm{H}\right\}$ NMR spectra for this compound were identical to the previously reported literature data. ${ }^{1}$

A $10 \mathrm{~mL}$ Schlenk flask was charged with bis(sulfonamide) ligand $\mathrm{L}_{2}^{*}(3.8$ $\mathrm{mg}, 0.01 \mathrm{mmol}), \mathrm{Ti}\left(\mathrm{O}^{t} \mathrm{Bu}\right)_{4}(193 \mu \mathrm{L}, 0.50 \mathrm{mmol})$, and $0.5 \mathrm{~mL}$ hexanes and stirred for 30 min at room temp. A hexanes solution of $\mathrm{Me}_{2} \mathrm{Zn}(0.32 \mathrm{~mL}, 0.63 \mathrm{mmol})$ was then added, and after stirring for $10 \mathrm{~min}$, cyclohexenecarboxaldehyde ( $28 \mu \mathrm{L}, 0.25 \mathrm{mmol})$ was added. The reaction was stirred at room temp for $19 \mathrm{~h}$ and quenched with a saturated solution of aq $\mathrm{NH}_{4} \mathrm{Cl}$. The organic and aqueous layers were separated, and the aqueous layer was extracted with hexanes $(3 \mathrm{X} 10 \mathrm{~mL})$. The combined organic layers were then washed with brine and $\mathrm{H}_{2} \mathrm{O}$ and dried over $\mathrm{MgSO}_{4}$. The filtrate was concentrated in vacuo and the residue was chromatographed on silica (10\% ethyl acetate in hexanes) to afford the 
title compound as a colorless oil in $94 \%$ yield $(30 \mathrm{mg}, 0.23 \mathrm{mmol}) .{ }^{1} \mathrm{H}$ NMR and ${ }^{13} \mathrm{C}\left\{{ }^{1} \mathrm{H}\right\}$ NMR spectra for this compound were identical to the previously reported literature data. ${ }^{1}$

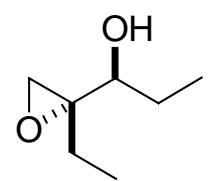

(Table 2, entry 1) erythro-1-(2-Ethyl-oxiranyl)-propan-1-ol. General Procedure C: Epoxidation with $\mathbf{T i}\left(\mathrm{O}^{i} \mathbf{P r}\right)_{4}$ and Dioxygen. A $10 \mathrm{~mL}$ Schlenk flask was charged with (-)-MIB (5.0 mg, $0.020 \mathrm{mmol})$ and $1 \mathrm{~mL}$ hexanes and cooled to $0{ }^{\circ} \mathrm{C}$. A hexanes solution of $\mathrm{Et}_{2} \mathrm{Zn}(0.5 \mathrm{~mL}, 2.0 \mathrm{M})$ was added, followed by addition of 2-ethylpropenal $(52 \mu \mathrm{L}, 0.5 \mathrm{mmol})$ dropwise. The reaction was stirred at $0{ }^{\circ} \mathrm{C}$ for $8 \mathrm{~h}$ until alkyl addition was complete by TLC. The reaction flask was then capped with a balloon of oxygen. After stirring at $0{ }^{\circ} \mathrm{C}$ for $1 \mathrm{~h}$, the reaction flask was cooled to $-20{ }^{\circ} \mathrm{C}$, and a hexanes solution of $\operatorname{Ti}\left(\mathrm{O}^{i} \mathrm{Pr}\right)_{4}(0.05 \mathrm{~mL}, 1.0 \mathrm{M})$ was added. The reaction continued to stir at $-20{ }^{\circ} \mathrm{C}$ under an $\mathrm{O}_{2}$ atmosphere for $18 \mathrm{~h}$. It was then quenched with $15 \%$ tartaric acid solution, allowed to stir for $45 \mathrm{~min}$, and poured into a separatory funnel with a solution of $\mathrm{Na}_{2} \mathrm{~S}_{2} \mathrm{O}_{4}$. The organic and aqueous layers were separated, and the aqueous layer was extracted with hexanes $(3 \mathrm{X} 10 \mathrm{~mL})$. The combined organic layers were then washed with brine and $\mathrm{H}_{2} \mathrm{O}$ and dried over $\mathrm{MgSO}_{4}$. The filtrate was concentrated in vacuo, and the residue was chromatographed on silica (20\% ethyl acetate in hexanes) to afford the title compound as a colorless oil in $60 \%$ yield (39 $\mathrm{mg}, 0.30$ mmol).

General Procedure D: Epoxidation with $\mathbf{T i}\left(\mathrm{O}^{i} \mathbf{P r}\right)_{\mathbf{4}}$ and TBHP. A $10 \mathrm{~mL}$ Schlenk flask was charged with (-)-MIB (4.8 mg, $0.020 \mathrm{mmol})$ and $2 \mathrm{~mL}$ of hexanes and 
cooled to $0{ }^{\circ} \mathrm{C}$. A hexanes solution of $\mathrm{Et}_{2} \mathrm{Zn}(0.75 \mathrm{~mL}, 2.0 \mathrm{M})$ was added, followed by addition of 2-ethylpropenal ( $49 \mu \mathrm{L}, 0.5 \mathrm{mmol})$ dropwise. The reaction was stirred at $0{ }^{\circ} \mathrm{C}$ for $20 \mathrm{~h}$ until alkyl addition was complete by TLC, then the reaction flask was cooled to $-20{ }^{\circ} \mathrm{C}$. A solution of $\operatorname{Ti}\left(\mathrm{O}^{i} \operatorname{Pr}\right)_{4}$ in dichloromethane $(100 \mu \mathrm{L}, 1.0 \mathrm{M})$ was added, followed by dropwise, careful addition of a decane solution of TBHP $(0.45 \mathrm{~mL}, 5.5 \mathrm{M})$. The reaction continued to stir at $-20{ }^{\circ} \mathrm{C}$ for $8 \mathrm{~h}$. It was then quenched with $4 \mathrm{~mL}$ saturated aq $\mathrm{NH}_{4} \mathrm{Cl}$, allowed to stir for $30 \mathrm{~min}$ at room temp, and poured into a separatory funnel with a solution of $\mathrm{Na}_{2} \mathrm{~S}_{2} \mathrm{O}_{4}$. The organic and aqueous layers were separated, and the aqueous layer was extracted with diethyl ether $(3 \times 5 \mathrm{~mL})$. The combined organic layers were then washed with $5 \mathrm{~mL}$ brine and $5 \mathrm{~mL} \mathrm{H}_{2} \mathrm{O}$ and dried over $\mathrm{MgSO}_{4}$. The filtrate was concentrated in vacuo, and the residue was chromatographed on silica (10\% ethyl acetate in hexanes) to afford the title compound as a colorless oil in 65\% yield (42 mg, 0.32 mmol). ${ }^{1} \mathrm{H}$ NMR and ${ }^{13} \mathrm{C}\left\{{ }^{1} \mathrm{H}\right\}$ NMR spectra for this compound were identical to the previously reported literature data. ${ }^{2}$

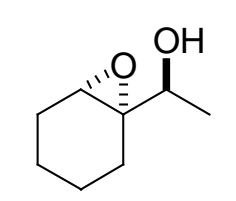

(Table 2, entry 9) erythro-1-(7-Oxa-bicyclo[4.1.0]hept-1-yl)-ethanol. General Procedure E: Epoxidation with $\mathrm{Ti}\left(\mathrm{O}^{t} \mathrm{Bu}\right)_{4}$ and Dioxygen. A 10 $\mathrm{mL}$ Schlenk flask was charged with bis(sulfonamide) ligand $\mathrm{L}_{2}{ }_{2}(3.8 \mathrm{mg}$, $0.01 \mathrm{mmol}), \mathrm{Ti}\left(\mathrm{O}^{t} \mathrm{Bu}\right)_{4}(97 \mu \mathrm{L}, 0.25 \mathrm{mmol})$, and $0.5 \mathrm{~mL}$ hexanes and stirred for $30 \mathrm{~min}$ at room temp. A hexanes solution of $\mathrm{Me}_{2} \mathrm{Zn}(0.25 \mathrm{~mL}, 0.50 \mathrm{mmol})$ was then added, and after stirring for $10 \mathrm{~min}$, cyclohexenecarboxaldehyde $(14 \mu \mathrm{L}, 0.13 \mathrm{mmol})$ was added. The reaction was stirred at room temp for $20 \mathrm{~h}$, until alkyl addition was complete by TLC, then cooled to $0{ }^{\circ} \mathrm{C}$. 1 equiv $\mathrm{Me}_{2} \mathrm{Zn}(63 \mu \mathrm{L}, 0.13 \mathrm{mmol})$ was added; the reaction 
flask was capped with a balloon of oxygen, warmed to room temperature and allowed to stir under an $\mathrm{O}_{2}$ atmosphere for $19 \mathrm{~h}$. It was then quenched with $15 \%$ tartaric acid solution, allowed to stir for $45 \mathrm{~min}$, poured into a separatory funnel with a solution of $\mathrm{Na}_{2} \mathrm{~S}_{2} \mathrm{O}_{4}$. The organic and aqueous layers were separated, and the aqueous layer was extracted with hexanes $(3 \mathrm{X} 10 \mathrm{~mL})$. The combined organic layers were then washed with brine and $\mathrm{H}_{2} \mathrm{O}$ and dried over $\mathrm{MgSO}_{4}$. The filtrate was concentrated in vacuo, and the residue was chromatographed on silica (10\% ethyl acetate in hexanes) to afford the title compound as a colorless oil in 78\% yield (14 $\mathrm{mg}, 0.099 \mathrm{mmol})$.

General Procedure F: Epoxidation with $\operatorname{Ti}\left(\mathrm{O}^{t} \mathbf{B u}\right)_{4}$ and TBHP. A $10 \mathrm{~mL}$ Schlenk flask was charged with bis(sulfonamide) ligand $\mathrm{L}_{2}^{*}(30 \mathrm{mg}, 0.08 \mathrm{mmol})$, $\mathrm{Ti}\left(\mathrm{O}^{t} \mathrm{Bu}\right)_{4}(0.77 \mathrm{~mL}, 2.0 \mathrm{mmol})$, and $1.0 \mathrm{~mL}$ of hexanes and stirred for $30 \mathrm{~min}$ at room temp. A hexanes solution of $\mathrm{Me}_{2} \mathrm{Zn}(2.0 \mathrm{~mL}, 4.0 \mathrm{mmol})$ was then added, and after stirring for $10 \mathrm{~min}$, cyclohexenecarboxaldehyde $(114 \mu \mathrm{L}, 1.0 \mathrm{mmol})$ was added. The reaction was stirred at room temp for $20 \mathrm{~h}$, until alkyl addition was complete by TLC, then cooled to $0{ }^{\circ} \mathrm{C}$. A solution of TBHP in decane $(0.91 \mathrm{~mL}, 5.5 \mathrm{M})$ was carefully added dropwise, and the stirring continued at $0{ }^{\circ} \mathrm{C}$ for $20 \mathrm{~h}$. It was then quenched with $4 \mathrm{~mL}$ saturated aq $\mathrm{NH}_{4} \mathrm{Cl}$, allowed to stir for $30 \mathrm{~min}$ at room temp, and poured into a separatory funnel with a solution of $\mathrm{Na}_{2} \mathrm{~S}_{2} \mathrm{O}_{4}$. The organic and aqueous layers were separated, and the aqueous layer was extracted with diethyl ether $(3 \times 5 \mathrm{~mL})$. The combined organic layers were then washed with $5 \mathrm{~mL}$ brine and $5 \mathrm{~mL} \mathrm{H}_{2} \mathrm{O}$ and dried over $\mathrm{MgSO}_{4}$. The filtrate was concentrated in vacuo, and the residue was chromatographed on silica (10\% ethyl acetate in hexanes) to afford the title compound as a colorless oil in 89\% yield (126 
mg, 0.89 mmol). ${ }^{1} \mathrm{H}$ NMR and ${ }^{13} \mathrm{C}\left\{{ }^{1} \mathrm{H}\right\}$ NMR spectra for this compound were identical to the previously reported literature data. ${ }^{3}$

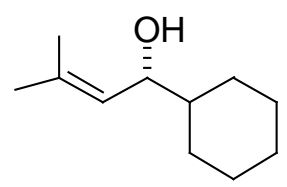

(Table 2, entry 13) (S)-1-Methyl-4-cyclohexyl-buten-4-ol. General

Procedure G. A $10 \mathrm{~mL}$ Schlenk flask was charged with $3.5 \mathrm{mg}(0.015$ mmol) (-)-MIB and a stir bar. Under a nitrogen atmosphere in a glovebox, the di(2methyl-propene)zinc reagent $(89.5 \mathrm{mg}, 0.51 \mathrm{mmol})$ was wieghed and added to the Schlenk flask. Toluene $(1.5 \mathrm{~mL})$ was added, followed by 3.1 equiv $\mathrm{Et}_{2} \mathrm{Zn}(115 \mu \mathrm{L}, 1.13$ mmol). After cooling to $0{ }^{\circ} \mathrm{C}$, cyclohexanecarboxaldehyde $(40.8 \mathrm{mg}, 0.36 \mathrm{mmol})$ was added dropwise. After the reaction was complete $(2 \mathrm{~h})$, it was quenched with saturated aq $\mathrm{NH}_{4} \mathrm{Cl}$. The organic and aqueous layers were separated and the aqueous layer was extracted with diethyl ether $(3 \times 25 \mathrm{~mL})$. The combined organic layers were washed with brine, dried over $\mathrm{MgSO}_{4}$ and concentrated. The crude product was purified by column chromatography on silica (70:20:10, hexanes: $\mathrm{CH}_{2} \mathrm{Cl}_{2}$ :EtOAc) to afford the title compound as a colorless oil in $75 \%$ yield $(45.8 \mathrm{mg}, 0.27 \mathrm{mmol}) .{ }^{1} \mathrm{H} \mathrm{NMR}$ and ${ }^{13} \mathrm{C}\left\{{ }^{1} \mathrm{H}\right\}$ NMR spectra for this compound were identical to the previously reported literature data. ${ }^{2}$

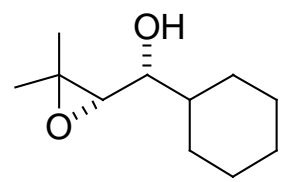

(Table 2, entry 13) threo-(S)-1-(1-Methyl-2-oxiranyl-4-cyclohexyl)butan-4-ol. General Procedure H. A $10 \mathrm{~mL}$ Schlenk flask was charged with $3.5 \mathrm{mg}(0.015 \mathrm{mmol})(-)-\mathrm{MIB}$ and a stir bar. Under a nitrogen atmosphere in a glovebox, the di(2-methyl-propene)zinc reagent $(89.5 \mathrm{mg}, 0.51 \mathrm{mmol})$ was weighed and added to the Schlenk flask. Toluene $(1.5 \mathrm{~mL})$ was added, followed by 3.1 equiv $\mathrm{Et}_{2} \mathrm{Zn}(115 \mu \mathrm{L}, 1.13 \mathrm{mmol})$. After cooling to $0{ }^{\circ} \mathrm{C}$, cyclohexanecarboxaldehyde (40.8 $\mathrm{mg}$, 
$0.36 \mathrm{mmol}$ ) was added dropwise. The reaction was stirred for $2 \mathrm{~h}$, then the solution was cooled to $-20{ }^{\circ} \mathrm{C}$, and saturated with 1 atm of $\mathrm{O}_{2}$ for $30 \mathrm{~min}$. A solution of $\operatorname{Ti}\left(\mathrm{O}^{i} \operatorname{Pr}\right)_{4}$ in toluene $(0.095 \mathrm{mmol}, 2.0 \mathrm{M})$ was added under an $\mathrm{N}_{2}$ purge dropwise, followed by resaturation of the solution with the $\mathrm{O}_{2}$ balloon. After stirring the reaction at $-20{ }^{\circ} \mathrm{C}$ for $12 \mathrm{~h}$, the flask was warmed to $0{ }^{\circ} \mathrm{C}$. The epoxidation reaction was stirred for $24 \mathrm{~h}$, then quenched with saturated aq $\mathrm{NH}_{4} \mathrm{Cl}$ and $8 \mathrm{~mL}$ aq $\mathrm{Na}_{2} \mathrm{CO}_{3}$. The pale yellow biphasic solution and salts were filtered through celite, washed with diethyl ether ( 2 X $25 \mathrm{~mL})$, and the aqueous layer was extracted with diethyl ether $(3 \mathrm{X} 30 \mathrm{~mL})$. The combined organic layers were washed with brine, dried over $\mathrm{MgSO}_{4}$ and concentrated. The crude product was purified by column chromatography on silica $\left(60: 30: 10\right.$, hexanes: $\mathrm{CH}_{2} \mathrm{Cl}_{2}$ : EtOAc) to afford the title compound as a colorless oil in $79 \%$ yield (68.9 $\mathrm{mg}, 0.37 \mathrm{mmol})$. ${ }^{1} \mathrm{H}$ NMR and ${ }^{13} \mathrm{C}\left\{{ }^{1} \mathrm{H}\right\}$ NMR spectra for this compound were identical to the previously reported literature data. ${ }^{2}$

Synthesis and full characterization of all of the compounds in Table 2 was reported in our communication. $^{2}$

\section{Compounds from Table 3.}

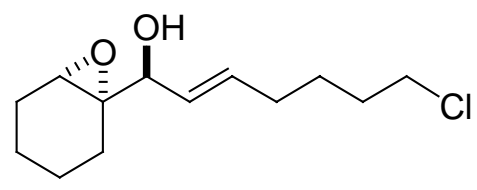

(1) erythro-(S)-7-Chloro-1-(7-oxa-bicyclo[4.1.0]hept-1yl)-hept-2-en-1-ol. General Procedure I. 6-Chloro-hex1-yne $[140 \mathrm{mg}(1.2 \mathrm{mmol})]$ and diethylborane $[1.2 \mathrm{~mL}(1.2$ mmol, 1.0 $\mathrm{M}$ in hexanes)] were stirred at room temp for $1 \mathrm{~h}$. The solvent was removed in vacuo, and $1 \mathrm{~mL}$ of hexanes was added. In a separate flask, $2.2 \mathrm{~mL}(2.2 \mathrm{mmol}, 1.0 \mathrm{M}$ in 
hexanes) diethylzinc, $9.6 \mathrm{mg}(0.04 \mathrm{mmol})(-)-\mathrm{MIB}$, and a $114 \mu \mathrm{L}(1.0 \mathrm{mmol})$ cyclohexenecarboxaldehyde were combined and stirred at $-78{ }^{\circ} \mathrm{C}$. The hydroboration product was cannulated into the reaction flask, and after $30 \mathrm{~min}$, the temperature was increased to $-10{ }^{\circ} \mathrm{C}$. The reaction was monitored by TLC until the addition was complete (6 h). The temperature was then decreased to $-20{ }^{\circ} \mathrm{C}$, the reaction headspace was purged, and the reaction was exposed to dioxygen. After $30 \mathrm{~min}, 200 \mu \mathrm{L}(0.20 \mathrm{mmol}, 1.0 \mathrm{M}$ in hexanes) $\operatorname{Ti}\left(\mathrm{O}^{i} \operatorname{Pr}\right)_{4}$ was added. The reaction proceded under 1 atm of $\mathrm{O}_{2}$. After the reaction was complete $(24 \mathrm{~h})$, it was quenched with saturated aq $\mathrm{NH}_{4} \mathrm{Cl}$ and extracted with hexanes ( 3 X $10 \mathrm{~mL}$ ). The crude product was dried over $\mathrm{MgSO}_{4}$, concentrated in vacuo, and purified by column chromatography on silica (10\% ethyl acetate in hexanes) to afford the title compound as a colorless oil in $78 \%$ yield $(191 \mathrm{mg}, 0.78 \mathrm{mmol}) .[\alpha]_{\mathrm{D}}{ }^{20}$ $=-2.16\left(c=0.74, \mathrm{CHCl}_{3}\right) ;{ }^{1} \mathrm{H} \mathrm{NMR}\left(\mathrm{CDCl}_{3}, 500 \mathrm{MHz}\right) \delta 1.25(\mathrm{~m}, 2 \mathrm{H}), 1.43(\mathrm{~m}, 2 \mathrm{H})$, $1.57(\mathrm{~s}, 4 \mathrm{H}), 1.76(\mathrm{~m}, 2 \mathrm{H}), 1.96(\mathrm{~m}, 2 \mathrm{H}), 2.10(\mathrm{q}, 2 \mathrm{H}, J=7.0 \mathrm{~Hz}), 2.32(\mathrm{br} \mathrm{s}, 1 \mathrm{H}), 3.23$ $(\mathrm{s}, 1 \mathrm{H}), 3.52(\mathrm{t}, 2 \mathrm{H}, J=5.0 \mathrm{~Hz}), 3.98(\mathrm{~d}, 1 \mathrm{H}, J=10.0 \mathrm{~Hz}), 5.40(\mathrm{dd}, 1 \mathrm{H}, J=10.0,15.0$ $\mathrm{Hz})$, and $5.77(\mathrm{dt}, 1 \mathrm{H}, J=5.0,15.0 \mathrm{~Hz}) \mathrm{ppm} ;{ }^{13} \mathrm{C}\left\{{ }^{1} \mathrm{H}\right\} \mathrm{NMR}\left(\mathrm{CDCl}_{3}, 125 \mathrm{MHz}\right) \delta 20.1$, $20.8,25.0,25.5,26.8,32.1,32.6,45.5,55.9,65.2,74.0,136.0$, and $140.9 \mathrm{ppm}$; IR (neat) 3387, 2920, 2860, 1615, 1430, 1259, and $1060 \mathrm{~cm}^{-1}$; HRMS-CI $\mathrm{m} / \mathrm{z}, 227.1204\left[(\mathrm{M}-\mathrm{OH})^{+}\right.$; calcd for $\mathrm{C}_{13} \mathrm{H}_{20} \mathrm{OCl}$ : 227.1203].

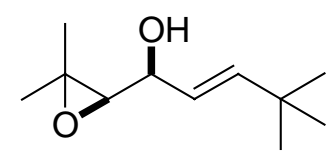

(2) threo-(S)-1-(3,3-Dimethyl-oxiranyl)-4,4-dimethyl-pent-2-en-

1-ol. The product was prepared by General Procedure I using 98.5 $\mathrm{mg}(1.2 \mathrm{mmol}) t$-butyl acetylene, $1.2 \mathrm{~mL}(1.2 \mathrm{mmol}, 1.0 \mathrm{M}$ in hexanes $)$ diethylborane, 2.2 $\mathrm{mL}(2.2 \mathrm{mmol}, 1.0 \mathrm{M}$ in hexanes) diethylzinc, $9.6 \mathrm{mg}(0.04 \mathrm{mmol})(-)-\mathrm{MIB}, 200 \mu \mathrm{L}$ 
(0.20 mmol, $1.0 \mathrm{M}$ in hexanes) $\mathrm{Ti}\left(\mathrm{O}^{i} \mathrm{Pr}\right)_{4}, 84 \mathrm{mg}(1.0 \mathrm{mmol})$ 3-methyl-but-2-enal. The crude product was purified by column chromatography on silica (10\% ethyl acetate in hexanes) to afford the title compound as a colorless oil in $76 \%$ yield (140 mg, 0.76 mmol). $[\alpha]_{\mathrm{D}}{ }^{20}=-4.04\left(c=0.94, \mathrm{CHCl}_{3}\right) ;{ }^{1} \mathrm{H} \mathrm{NMR}\left(\mathrm{CDCl}_{3}, 500 \mathrm{MHz}\right) \delta 1.02(\mathrm{~s}, 9 \mathrm{H})$, $1.24(\mathrm{~s}, 3 \mathrm{H}), 1.25(\mathrm{~s}, 3 \mathrm{H}), 2.04(\mathrm{br} \mathrm{s}, 1 \mathrm{H}), 2.75(\mathrm{~d}, 1 \mathrm{H}, J=8.0 \mathrm{~Hz}), 3.94(\mathrm{t}, 1 \mathrm{H}, J=5.5$ $\mathrm{Hz}), 5.4(\mathrm{dd}, 1 \mathrm{H}, J=6.1,15.0 \mathrm{~Hz})$ and $5.76(\mathrm{~d}, 1 \mathrm{H}, J=10.0 \mathrm{~Hz}) \mathrm{ppm} ;{ }^{13} \mathrm{C}\left\{{ }^{1} \mathrm{H}\right\} \mathrm{NMR}$ $\left(\mathrm{CDCl}_{3}, 125 \mathrm{MHz}\right) \delta 19.3,24.8,24.9,29.3,67.0,72.0,78.1,122.6$, and $144.7 \mathrm{ppm} ; \mathrm{IR}$ (neat) $3365,2957,2854,1618,1380,1261$, and $1091 \mathrm{~cm}^{-1}$; HRMS-CI $\mathrm{m} / \mathrm{z} 167.1439$ $\left[(\mathrm{M}-\mathrm{OH})^{+}\right.$; calcd for $\left.\mathrm{C}_{11} \mathrm{H}_{19} \mathrm{O}: 167.1436\right]$.

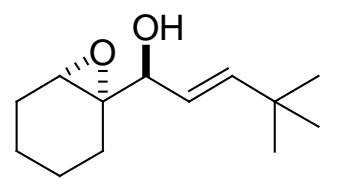

(3) erythro-(S)-4,4-Dimethyl-1-(7-oxa-bicyclo[4.1.0]hept-1-yl)using $98.5 \mathrm{mg}(1.2 \mathrm{mmol}) \mathrm{t}$-butyl acetylene, $1.2 \mathrm{~mL}(1.2 \mathrm{mmol}, 1.0 \mathrm{M}$ in hexanes $)$ diethylborane, $2.2 \mathrm{~mL}(2.2 \mathrm{mmol}, 1.0 \mathrm{M}$ in hexanes) diethylzinc, $9.6 \mathrm{mg}(0.04 \mathrm{mmol})$ (-)-MIB, $200 \mu \mathrm{L}(0.20 \mathrm{mmol}, 1.0 \mathrm{M}$ in hexanes $) \mathrm{Ti}\left(\mathrm{O}^{i} \mathrm{Pr}\right)_{4}$, and $114 \mu \mathrm{L}(1.0 \mathrm{mmol})$ cyclohexenecarboxaldehyde. The crude product was purified by column chromatography on silica ( $10 \%$ ethyl acetate in hexanes) to afford the title compound as a colorless oil in $87 \%$ yield $(183 \mathrm{mg}, 0.87 \mathrm{mmol}) .[\alpha]_{\mathrm{D}}{ }^{20}=-3.50\left(c=0.40, \mathrm{CHCl}_{3}\right) ;{ }^{1} \mathrm{H} \mathrm{NMR}\left(\mathrm{CDCl}_{3}\right.$, $500 \mathrm{MHz}) \delta 1.05(\mathrm{~s}, 9 \mathrm{H}), 1.28(\mathrm{~m}, 2 \mathrm{H}), 1.47(\mathrm{~m}, 2 \mathrm{H}), 1.78(\mathrm{~m}, 2 \mathrm{H}), 2.00(\mathrm{~m}, 2 \mathrm{H}), 2.32$ (br s, 1H), $3.27(\mathrm{~s}, 1 \mathrm{H}), 4.01(\mathrm{~d}, 1 \mathrm{H}, J=6.1 \mathrm{~Hz}), 5.31(\mathrm{dd}, 1 \mathrm{H}, J=5.9,14.9 \mathrm{~Hz})$, and $5.88(\mathrm{~d}, 1 \mathrm{H}, J=14.9 \mathrm{~Hz}) \mathrm{ppm} ;{ }^{13} \mathrm{C}\left\{{ }^{1} \mathrm{H}\right\} \mathrm{NMR}\left(\mathrm{CDCl}_{3}, 125 \mathrm{MHz}\right) \delta 19.7,20.2,24.5$, 24.9, 29.4, 35.1, 55.1, 62.0, 73.6, 122.6, and $146.6 \mathrm{ppm}$; IR (neat) 3431, 2931, 2859, 2666, 2360, 1607, 1448, 1440, 1362, 1261, and $1013 \mathrm{~cm}^{-1}$; HRMS- CI $\mathrm{m} / \mathrm{z} 210.1621\left[\mathrm{M}^{+}\right.$; calcd for $\left.\mathrm{C}_{13} \mathrm{H}_{22} \mathrm{O}_{2}: 210.1620\right]$. 


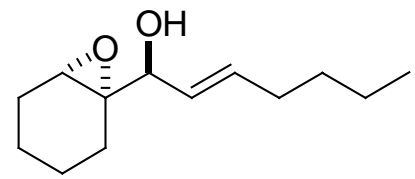

(4) erythro-(S)-1-(7-Oxa-bicyclo[4.1.0]hept-1-yl)-hept-2-en-

1-ol. The product was prepared by General Procedure I using $98.6 \mathrm{mg}$ (1.2 mmol) 1-hexyne, $1.2 \mathrm{~mL}$ (1.2 mmol, 1.0 $\mathrm{M}$ in hexanes) $\mathrm{Et}_{2} \mathrm{BH}, 2.2 \mathrm{~mL}$ (2.2 mmol, 1.0 $\mathrm{M}$ in hexanes) diethylzinc, $9.6 \mathrm{mg}(0.04 \mathrm{mmol})(-)-\mathrm{MIB}, 114 \mu \mathrm{L}(1.0 \mathrm{mmol})$ cyclohexenecarboxaldehyde, and $200 \mu \mathrm{L}(0.20 \mathrm{mmol}, 1.0 \mathrm{M}$ in hexanes $) \operatorname{Ti}\left(\mathrm{O}^{i} \mathrm{Pr}\right)_{4}$ was added to the reaction vessel. The crude product was purified by column chromatography on silica treated with triethylamine (10\% ethyl acetate in hexanes) to afford the title compound as a colorless oil in $78 \%$ yield $(164 \mathrm{mg}, 0.78 \mathrm{mmol}) .[\alpha]_{\mathrm{D}}{ }^{20}=-1.79(c=1.78$, $\left.\mathrm{CHCl}_{3}\right) ;{ }^{1} \mathrm{H} \mathrm{NMR}\left(\mathrm{C}_{6} \mathrm{D}_{6}, 360 \mathrm{MHz}\right) \delta 0.85(\mathrm{t}, 3 \mathrm{H}, J=5.0 \mathrm{~Hz}), 1.03(\mathrm{~m}, 2 \mathrm{H}), 1.27(\mathrm{~m}$, 4H), $1.38(\mathrm{~m}, 4 \mathrm{H}), 1.78(\mathrm{~m}, 4 \mathrm{H}), 1.97(\mathrm{~m}, 1 \mathrm{H}), 2.22$ (br s, 1H), $3.13(\mathrm{~s}, 1 \mathrm{H}), 3.95(\mathrm{~d}, 1 \mathrm{H}$, $J=8.0 \mathrm{~Hz}), 5.52(\mathrm{dd}, 1 \mathrm{H}, J=8.0,15.0 \mathrm{~Hz})$, and $5.72(\mathrm{~m}, 1 \mathrm{H}) ;{ }^{13} \mathrm{C}\left\{{ }^{1} \mathrm{H}\right\} \mathrm{NMR}\left(\mathrm{C}_{6} \mathrm{D}_{6}, 90.6\right.$ MHz) $\delta 13.7,19.7,20.4,22.1,24.6,24.8,31.3,32.0,54.9,61.5,73.6,128.8$, and 133.9 ppm; IR (neat) 3402, 2925, 2856, 1722, 1445, 1260, 1021, and $800 \mathrm{~cm}^{-1}$; HRMS-ESI $\mathrm{m} / z$ 210.1626 [M ; calcd for $\mathrm{C}_{13} \mathrm{H}_{22} \mathrm{O}_{2}$ : 210.1620].

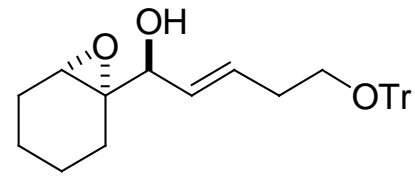

(5) erythro-(S)-1-(7-Oxa-bicyclo[4.1.0]hept-1-yl)-3-trityloxyprop-2-en-1-ol. General Procedure J. 374 mg (1.2 mmol) trityl protected 3-butyn-1-ol, was added to $1.2 \mathrm{~mL}\left(1.2 \mathrm{mmol}, 1.0 \mathrm{M}\right.$ in hexanes) $\mathrm{Et}_{2} \mathrm{BH}$ and stirred at room temp for $1 \mathrm{~h}$. The solvent was removed in vacuo, and $1 \mathrm{~mL}$ of hexanes was added. In a separate flask, $9.6 \mathrm{mg}(0.04 \mathrm{mmol})(-)-\mathrm{MIB}, 114 \mu \mathrm{L}(1.0$ mmol) cyclohexenecarboxaldehyde, $1 \mathrm{~mL}$ of toluene, and $2.2 \mathrm{~mL}(2.2 \mathrm{mmol}, 1.0 \mathrm{M}$ in hexanes) diethylzinc were combined and stirred at $-30{ }^{\circ} \mathrm{C}$. The hydroboration product 
was added to the reaction flask via syringe pump over $30 \mathrm{~min}$, and the reaction was monitored by TLC. When no enal remained (after $5 \mathrm{~h}$ ), the temperature was increased to $-20{ }^{\circ} \mathrm{C}$, the reaction headspace was purged, and the reaction was exposed to dioxygen (1 atm). After $30 \mathrm{~min}, 200 \mu \mathrm{L}(0.20 \mathrm{mmol}, 1.0 \mathrm{M}$ in hexanes $) \mathrm{Ti}\left(\mathrm{O}^{i} \mathrm{Pr}\right)_{4}$ was added to the reaction vessel. After the reaction was complete, it was quenched with saturated aq $\mathrm{NH}_{4} \mathrm{Cl}$ and extracted with hexanes $(3 \mathrm{X} 10 \mathrm{~mL})$. The crude product was dried over $\mathrm{MgSO}_{4}$, concentrated in vacuo, and purified by column chromatography on silica (10\% ethyl acetate in hexanes) to afford the title compound as a colorless oil in $60 \%$ yield (264 $\mathrm{mg}, 0.60 \mathrm{mmol}) .[\alpha]_{\mathrm{D}}{ }^{20}=-0.504\left(c=1.19, \mathrm{CHCl}_{3}\right) ;{ }^{1} \mathrm{H} \mathrm{NMR}\left(\mathrm{CDCl}_{3}, 500 \mathrm{MHz}\right) \delta 1.21$ $(\mathrm{s}, 2 \mathrm{H}), 1.77(\mathrm{~m}, 2 \mathrm{H}), 1.81(\mathrm{~m}, 2 \mathrm{H}), 2.00(\mathrm{~m}, 2 \mathrm{H}), 2.13(\mathrm{~m}, 2 \mathrm{H}), 2.34(\mathrm{br} \mathrm{s}, 1 \mathrm{H}), 2.80(\mathrm{~s}$, 2H), $3.57(\mathrm{~d}, 1 \mathrm{H}, J=3.5 \mathrm{~Hz}), 3.80(\mathrm{~s}, 1 \mathrm{H}), 5.46(\mathrm{~m}, 1 \mathrm{H}), 5.5(\mathrm{~m}, 1 \mathrm{H})$, and $7.28(\mathrm{~m}, 15 \mathrm{H})$ ppm; ${ }^{13} \mathrm{C}\left\{{ }^{1} \mathrm{H}\right\} \operatorname{NMR}\left(\mathrm{CDCl}_{3}, 125 \mathrm{MHz}\right) \delta 12.7,13.5,15.1,20.4,21.4,21.6,61.0,64.1$, 68.3, 73.6, 127.0, 127.4, 128.3, 128.5, 133.1, and $138.6 \mathrm{ppm}$; IR (neat) 3308, 3058, 2924, 2359, 1597, 1489, 1446, 1369, 1155, 1063, and $896 \mathrm{~cm}^{-1}$; HRMS-CI m/z $440.2359\left[\mathrm{M}^{+}\right.$; calcd for $\mathrm{C}_{30} \mathrm{H}_{32} \mathrm{O}_{3}$ : 440.2351].

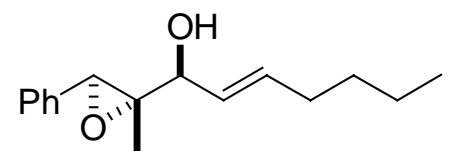

(6) erythro-(S)-1-(2-Methyl-3-phenyl-oxiranyl)-hept-2-en-

1-ol. The product was prepared by General Procedure I using $98.6 \mathrm{mg}$ (1.2 mmol) 1-hexyne, $1.2 \mathrm{~mL}$ (1.2 mmol, 1.0 $\mathrm{M}$ in hexanes) $\mathrm{Et}_{2} \mathrm{BH}, 2.2 \mathrm{~mL}$ (2.2 mmol, 1.0 M in hexanes) diethylzinc, $9.6 \mathrm{mg}(0.04 \mathrm{mmol})(-)-\mathrm{MIB}, 200 \mu \mathrm{L}$ (0.20 mmol, 1.0 $\mathrm{M}$ in hexanes) $\mathrm{Ti}\left(\mathrm{O}^{i} \mathrm{Pr}\right)_{4}$, and $146 \mathrm{mg}(1.0 \mathrm{mmol}) \alpha$-methyl-trans-cinnamaldehyde. The crude product was purified by column chromatography on silica (10\% ethyl acetate in hexanes) to afford the title compound as a colorless oil in $80 \%$ yield (197 $\mathrm{mg}, 0.80$ mmol). $[\alpha]_{\mathrm{D}}{ }^{20}=-0.963\left(c=1.04, \mathrm{CHCl}_{3}\right) ;{ }^{1} \mathrm{H} \mathrm{NMR}\left(\mathrm{CDCl}_{3}, 500 \mathrm{MHz}\right) \delta 0.92(\mathrm{t}, 3 \mathrm{H}, J$ 
$=9.0 \mathrm{~Hz}), 1.01(\mathrm{~m}, 2 \mathrm{H}), 1.39(\mathrm{~m}, 2 \mathrm{H}), 1.56(\mathrm{~s}, 3 \mathrm{H}), 2.01(\mathrm{~m}, 2 \mathrm{H}), 2.34(\mathrm{~s}, 1 \mathrm{H}), 2.66(\mathrm{br} \mathrm{s}$, $1 \mathrm{H}), 4.22(\mathrm{~d}, 1 \mathrm{H}, J=6.0 \mathrm{~Hz}), 5.50(\mathrm{dd}, 1 \mathrm{H} J=15.0,6.0 \mathrm{~Hz}), 5.85(\mathrm{dt}, 1 \mathrm{H}, J=15.0,6.0$ $\mathrm{Hz})$, and $7.35(\mathrm{~m}, 5 \mathrm{H}), \mathrm{ppm} ;{ }^{13} \mathrm{C}\left\{{ }^{1} \mathrm{H}\right\} \mathrm{NMR}\left(\mathrm{CDCl}_{3}, 125 \mathrm{MHz}\right) \delta$ 13.5, 13.8, 22.2, 31.1, 32.0, 59.4, 65.9, 73.9, 126.3, 127.4, 127.5, 127.9, 128.1, and $136.1 \mathrm{ppm}$; IR (neat) 3388, 2924, 1628, 1442, 1262, and $1090 \mathrm{~cm}^{-1}$; HRMS-CI $\mathrm{m} / z$ 229.1601 [(M-OH $)^{+}$; calcd for $\left.\mathrm{C}_{16} \mathrm{H}_{21} \mathrm{O}_{1}: 229.1592\right]$.

\section{Compounds from Table 4.}

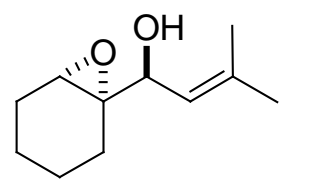

(1) erythro-(S)-3-Methyl-1-(7-oxa-bicyclo[4.1.0]hept-1-yl)-but-2-en-

1-ol. General Procedure K. Di(2-methyl-propene)zinc $(86 \mathrm{mg}, 0.5$ $\mathrm{mmol}), 1.5 \mathrm{~mL}(1.5 \mathrm{mmol}, 1.0 \mathrm{M}$ in hexanes) diethylzinc, $9.6 \mathrm{mg}(0.04 \mathrm{mmol})(-)-\mathrm{MIB}$, and $1 \mathrm{~mL}$ of toluene were combined and stirred at $0{ }^{\circ} \mathrm{C} . \quad 114 \mu \mathrm{L}(1.0 \mathrm{mmol})$ cyclohexenecarboxaldehyde was added, and the reaction was monitored by TLC. When no enal remained (after $6 \mathrm{~h}$ ), the temperature was decreased to $-20{ }^{\circ} \mathrm{C}$, the reaction headspace was purged, and the reaction was exposed to dioxygen $(1 \mathrm{~atm})$. After $30 \mathrm{~min}$, $200 \mu \mathrm{L}\left(0.20 \mathrm{mmol}, 1.0 \mathrm{M}\right.$ in hexanes) $\mathrm{Ti}\left(\mathrm{O}^{i} \mathrm{Pr}\right)_{4}$ was added to the reaction vessel. After the reaction was complete, it was quenched with saturated aq $\mathrm{NH}_{4} \mathrm{Cl}$ and extracted with hexanes ( $3 \mathrm{X} 10 \mathrm{~mL}$ ). The crude product was dried over $\mathrm{MgSO}_{4}$, concentrated in vacuo, and purified by column chromatography on silica (10\% ethyl acetate in hexanes) to afford the title compound as a colorless oil in $61 \%$ yield $(111 \mathrm{mg}, 0.61 \mathrm{mmol}) .[\alpha]_{\mathrm{D}}{ }^{20}=$ $-3.33\left(c=0.24, \mathrm{CHCl}_{3}\right) ;{ }^{1} \mathrm{H} \mathrm{NMR}\left(\mathrm{CDCl}_{3}, 500 \mathrm{MHz}\right) \delta 0.89(\mathrm{~m}, 2 \mathrm{H}), 1.31($ br s, $1 \mathrm{H})$, $1.54(\mathrm{~m}, 2 \mathrm{H}), 1.65(\mathrm{~m}, 2 \mathrm{H}), 1.73(\mathrm{~s}, 3 \mathrm{H}), 1.75(\mathrm{~s}, 3 \mathrm{H}), 1.78(\mathrm{~m}, 2 \mathrm{H}), 3.27(\mathrm{~s}, 1 \mathrm{H}), 4.31(\mathrm{~d}$, $1 \mathrm{H}, J=9.1 \mathrm{~Hz})$, and $5.06(\mathrm{~d}, 1 \mathrm{H}, J=9.2 \mathrm{~Hz}) \mathrm{ppm} ;{ }^{13} \mathrm{C}\left\{{ }^{1} \mathrm{H}\right\} \mathrm{NMR}\left(\mathrm{C}_{6} \mathrm{D}_{6}, 90.6 \mathrm{MHz}\right) \delta$ 
$18.3,19.9,20.4,24.6,25.0,25.6,54.4,62.0,68.9,124.3$, and 136.9 ppm; IR (neat) 3430,

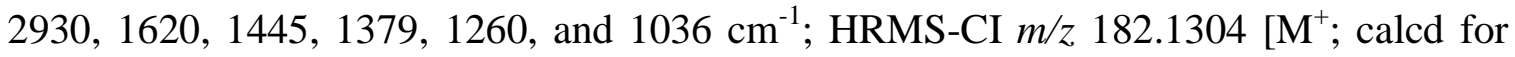
$\mathrm{C}_{11} \mathrm{H}_{18} \mathrm{O}_{2}$ : 182.1307].

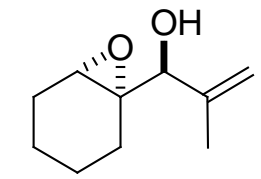

\section{(2) erythro-(S)-2-Methyl-1-(7-oxa-bicyclo[4.1.0]hept-1-yl)-prop-2-en-}

1-ol. The product was prepared by General Procedure $\mathrm{K}$ using using di(1-methyl-ethylene)zinc (73 mg, $0.5 \mathrm{mmol}), 1.5 \mathrm{~mL}(1.5 \mathrm{mmol}, 1.0 \mathrm{M}$ in hexanes) diethylzinc, $\quad 9.6 \quad \mathrm{mg} \quad(0.04 \quad \mathrm{mmol}) \quad(-)$-MIB, $114 \quad \mu \mathrm{L} \quad\left(\begin{array}{llll}1.0 & \mathrm{mmol}\end{array}\right)$ cyclohexenecarboxaldehyde, and $200 \mu \mathrm{L}(0.20 \mathrm{mmol}, 1.0 \mathrm{M}$ in hexanes $) \operatorname{Ti}\left(\mathrm{O}^{i} \mathrm{Pr}\right)_{4}$. The crude product was purified by column chromatography on silica (10\% ethyl acetate in hexanes) to afford the title compound as a colorless oil in $90 \%$ yield (151 mg, 0.90 mmol). $[\alpha]_{\mathrm{D}}{ }^{20}=-5.83\left(c=1.2, \mathrm{CHCl}_{3}\right) ;{ }^{1} \mathrm{H} \mathrm{NMR}\left(\mathrm{CDCl}_{3}, 500 \mathrm{MHz}\right) \delta 1.23(\mathrm{~m}, 2 \mathrm{H})$, $1.54(\mathrm{~s}, 3 \mathrm{H}), 1.67(\mathrm{~m}, 2 \mathrm{H}), 1.79(\mathrm{~m}, 2 \mathrm{H}), 1.93(\mathrm{~m}, 2 \mathrm{H}), 2.02$ (br s, 1H), $3.35(\mathrm{~s}, 1 \mathrm{H}), 4.03$ $(\mathrm{s}, 1 \mathrm{H}), 4.99(1 \mathrm{H}, \mathrm{s})$, and $5.05(\mathrm{~s}, 1 \mathrm{H}) \mathrm{ppm} ;{ }^{13} \mathrm{C}\left\{{ }^{1} \mathrm{H}\right\} \mathrm{NMR}\left(\mathrm{C}_{6} \mathrm{D}_{6}, 90.6 \mathrm{MHz}\right) \delta 18.1$, 19.7, 20.2, 24.4, 24.6, 54.9, 60.5, 76.4, 113.8, and $144.3 \mathrm{ppm}$; IR (neat) 3398, 2360, 1621, 1498, 1220, and $1007 \mathrm{~cm}^{-1}$; LRMS-CI m/z $167.11\left[(\mathrm{M}-\mathrm{H})^{+}\right.$; calcd for $\mathrm{C}_{10} \mathrm{H}_{15} \mathrm{O}_{2}$ : 167.11].

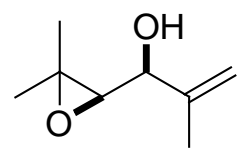

(3) threo-(S)-1-(3,3,-Dimethyl-oxiranyl)-2-methyl-prop-2-en-1-ol. The product was prepared by General Procedure K using using Di(1-methylethylene)zinc (73 mg, $0.5 \mathrm{mmol}), 1.5 \mathrm{~mL}$ (1.5 mmol, $1.0 \mathrm{M}$ in hexanes) diethylzinc, 9.6 $\mathrm{mg}(0.04 \mathrm{mmol})(-)-\mathrm{MIB}, 84 \mathrm{mg}(1.0 \mathrm{mmol})$ 3-methyl-but-2-enal, and $200 \mu \mathrm{L}(0.20$ mmol, 1.0 $\mathrm{M}$ in hexanes) $\operatorname{Ti}\left(\mathrm{O}^{i} \mathrm{Pr}\right)_{4}$. The crude product was purified by column chromatography on silica (10\% ethyl acetate in hexanes) to afford the title compound as a 
colorless oil in $91 \%$ yield $(194 \mathrm{mg}, 0.43 \mathrm{mmol}) .[\alpha]_{\mathrm{D}}{ }^{20}=-5.00\left(c=0.22, \mathrm{CHCl}_{3}\right) ;{ }^{1} \mathrm{H}$ NMR $\left(\mathrm{CDCl}_{3}, 500 \mathrm{MHz}\right) \delta 1.29(\mathrm{~s}, 3 \mathrm{H}), 1.30$ (s, 3H), $1.74(\mathrm{~s}, 3 \mathrm{H}), 2.02$ (br s, 1H), 2.73 $(\mathrm{d}, 1 \mathrm{H}, J=6.0 \mathrm{~Hz}), 3.87(\mathrm{~d}, 1 \mathrm{H}, J=6.0 \mathrm{~Hz}), 4.90(\mathrm{~s}, 1 \mathrm{H})$, and $5.02(\mathrm{~s}, 1 \mathrm{H}) \mathrm{ppm} ;{ }^{13} \mathrm{C}\left\{{ }^{1} \mathrm{H}\right\}$ NMR $\left(\mathrm{C}_{6} \mathrm{D}_{6}, 125 \mathrm{MHz}\right) \delta 18.9,19.5,24.8,59.3,67.1,73.7,111.7$, and $128.4 \mathrm{ppm}$; IR (neat) 3390, 2950, 2924, 1601, 1430, 1260, and $1090 \mathrm{~cm}^{-1}$; HRMS-CI $\mathrm{m} / z .125 .0966$ $\left[(\mathrm{M}-\mathrm{OH})^{+}\right.$; calcd for $\left.\mathrm{C}_{8} \mathrm{H}_{13} \mathrm{O}_{1}: 125.0966\right]$.

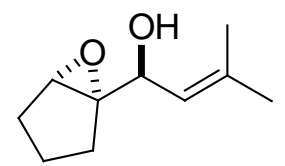

(4) erythro-(S)-3-Methyl-1-(6-oxa-bicyclo[3.1.0]hex-1-yl)-but-2-en-

1-ol. The product was prepared by General Procedure K using di(2methyl-propene)zinc (86 mg, $0.5 \mathrm{mmol}), 1.5 \mathrm{~mL}(1.5 \mathrm{mmol}, 1.0 \mathrm{M}$ in hexanes) diethylzinc, $\quad 9.6 \quad \mathrm{mg} \quad(0.04 \quad \mathrm{mmol}) \quad(-)-\mathrm{MIB}, \quad 96 \quad \mathrm{mg} \quad\left(\begin{array}{llll}1.0 & \mathrm{mmol}\end{array}\right)$ cyclopentanecarboxaldehyde, and $200 \mu \mathrm{L}(0.20 \mathrm{mmol}, 1.0 \mathrm{M}$ in hexanes $) \mathrm{Ti}\left(\mathrm{O}^{i} \mathrm{Pr}\right)_{4}$. The crude product was purified by column chromatography on silica (10\% ethyl acetate in hexanes) to afford the title compound as a colorless oil in $76 \%$ yield $(127.7 \mathrm{mg}, 0.76$ mmol). $[\alpha]_{\mathrm{D}}{ }^{20}=-5.00\left(c=1.0, \mathrm{CHCl}_{3}\right) ;{ }^{1} \mathrm{H} \mathrm{NMR}\left(\mathrm{CDCl}_{3}, 500 \mathrm{MHz}\right) \delta 1.28(\mathrm{~m}, 2 \mathrm{H})$, $1.55(\mathrm{~m}, 2 \mathrm{H}), 1.56(\mathrm{~s}, 3 \mathrm{H}), 1.67(\mathrm{~s}, 3 \mathrm{H}), 1.80(\mathrm{~m}, 2 \mathrm{H}), 1.98$ (br s, 1H), $3.44(\mathrm{~s}, 1 \mathrm{H}), 4.61$ $(\mathrm{d}, 1 \mathrm{H}, J=10.0 \mathrm{~Hz})$, and $5.08(\mathrm{~d}, 1 \mathrm{H}, J=10.0 \mathrm{~Hz}) \mathrm{ppm} ;{ }^{13} \mathrm{C}\left\{{ }^{1} \mathrm{H}\right\} \mathrm{NMR}\left(\mathrm{C}_{6} \mathrm{D}_{6}, 75 \mathrm{MHz}\right)$ $\delta 18.7,20.1,26.1,27.2,27.8,60.7,67.3,71.1,125.8$ and $137.5 \mathrm{ppm}$; IR (neat) 3410 , 2957, 1624, 1413, 1261, 1089, and $800 \mathrm{~cm}^{-1}$; LRMS-CI m/z $167.23\left[(\mathrm{M}-\mathrm{H})^{+}\right.$; calcd for $\left.\mathrm{C}_{10} \mathrm{H}_{15} \mathrm{O}_{2}: 167.22\right]$. 


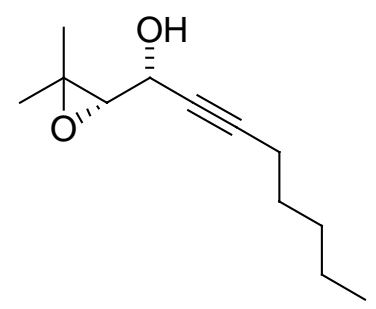

(5) threo-(S)-1-(3,3-Dimethyl-oxiranyl)-oct-2-yn-1-ol. The product was prepared by General Procedure K using di(2-methylpropene)zinc ( $86 \mathrm{mg}, 0.5 \mathrm{mmol}), 1.5 \mathrm{~mL}(1.5 \mathrm{mmol}, 1.0 \mathrm{M}$ in hexanes) diethylzinc, $9.6 \mathrm{mg}(0.04 \mathrm{mmol})(-)-\mathrm{MIB}, 124.1 \mathrm{mg}(1.0$ mmol) oct-2-ynal, and $200 \mu \mathrm{L}(0.20 \mathrm{mmol}, 1.0 \mathrm{M}$ in hexanes $) \operatorname{Ti}\left(\mathrm{O}^{i} \operatorname{Pr}\right)_{4}$. The crude product was purified by column chromatography on silica (10\% ethyl acetate in hexanes) to afford the title compound as a colorless oil in $92 \%$ yield $(180 \mathrm{mg}, 0.92 \mathrm{mmol}) .[\alpha]_{\mathrm{D}}{ }^{20}=$ $-0.571\left(c=0.35, \mathrm{CHCl}_{3}\right) ;{ }^{1} \mathrm{H} \mathrm{NMR}\left(\mathrm{CDCl}_{3}, 500 \mathrm{MHz}\right) \delta 0.87(\mathrm{t}, 3 \mathrm{H}, J=5.0 \mathrm{~Hz}), 1.23$ (m, 2H), $1.32(\mathrm{~s}, 3 \mathrm{H}), 1.33(\mathrm{~s}, 3 \mathrm{H}), 1.49(\mathrm{q}, 2 \mathrm{H}, J=7.0 \mathrm{~Hz}), 2.01$ (br s, 1H), $2.14(\mathrm{~d}, 2 \mathrm{H}$, $J=2.0 \mathrm{~Hz}), 2.20(\mathrm{t}, 2 \mathrm{H}, J=8.7 \mathrm{~Hz}), 2.94(\mathrm{~d}, 1 \mathrm{H}, J=7.8 \mathrm{~Hz})$, and $4.15(\mathrm{~d}, 1 \mathrm{H}, J=7.8$ Hz) ppm; ${ }^{13} \mathrm{C}\left\{{ }^{1} \mathrm{H}\right\}$ NMR $\left(\mathrm{C}_{6} \mathrm{D}_{6}, 90.6 \mathrm{MHz}\right) \delta 13.8,18.6,18.8,22.2,24.3,28.3,30.9$, 58.0, 62.6, 67.0, 78.4, and 86.8 ppm; IR (neat) 3391, 2979, 2969, 2929, 2359, 2101, 1457, 1380, 1260, 1092, and $1020 \mathrm{~cm}^{-1}$; HRMS-CI $\mathrm{m} / z 197.1542\left[(\mathrm{M}+\mathrm{H})^{+}\right.$; calcd for $\left.\mathrm{C}_{12} \mathrm{H}_{21} \mathrm{O}_{2}: 197.1538\right]$

(6) erythro-(S)-1-(2-Methyl-oxiranyl)-oct-2-yn-1-ol. The

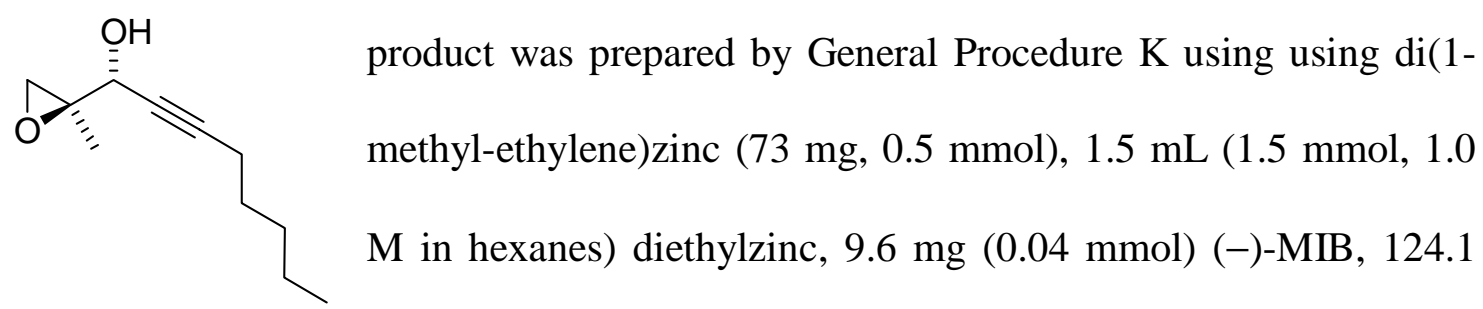
mg $(1.0 \mathrm{mmol})$ oct-2-ynal, and $200 \mu \mathrm{L}(0.20 \mathrm{mmol}, 1.0 \mathrm{M}$ in hexanes $) \mathrm{Ti}\left(\mathrm{O}^{i} \mathrm{Pr}\right)_{4}$. The crude product was purified by column chromatography on silica (10\% ethyl acetate in hexanes) to afford the title compound as a colorless oil in 90\% yield (164 mg, 0.90 
mmol). $[\alpha]_{\mathrm{D}}{ }^{20}=-0.590\left(c=0.21, \mathrm{CHCl}_{3}\right) ;{ }^{1} \mathrm{H} \mathrm{NMR}\left(\mathrm{CDCl}_{3}, 500 \mathrm{MHz}\right) \delta 0.88(\mathrm{q}, 3 \mathrm{H}, J$ $=5.0 \mathrm{~Hz}), 1.23(\mathrm{~m}, 4 \mathrm{H}), 1.32(\mathrm{~s}, 3 \mathrm{H}), 1.51(\mathrm{~m}, 2 \mathrm{H}), 2.05(\mathrm{br} \mathrm{s}, 1 \mathrm{H}), 2.22(\mathrm{t}, 2 \mathrm{H}, J=8.0$ $\mathrm{Hz}), 2.65(\mathrm{~d}, 1 \mathrm{H}, J=5.0 \mathrm{~Hz}), 2.99(\mathrm{~d}, 1 \mathrm{H}, J=5.0 \mathrm{~Hz}), 4.36(\mathrm{~s}, 1 \mathrm{H}) \mathrm{ppm} ;{ }^{13} \mathrm{C}\left\{{ }^{1} \mathrm{H}\right\} \mathrm{NMR}$ $\left(\mathrm{C}_{6} \mathrm{D}_{6}, 90.6 \mathrm{MHz}\right) \delta 13.8,17.2,18.6,22.2,28.3,30.7,50.7,58.3,64.8,78.3$, and 86.3 ppm; IR (neat) 3360, 2923, 2359, 2126, 1731, 1461 and $1154 \mathrm{~cm}^{-1}$; HRMS-CI $\mathrm{m} / z$ $183.1389\left[(\mathrm{M}+\mathrm{H})^{+}\right.$; calcd for $\left.\mathrm{C}_{11} \mathrm{H}_{19} \mathrm{O}_{2}: 183.1385\right]$. erythro-(S)-4-(Isopropyl-diphenyl-silanyloxy)-1-(2-methylOTBDPS oxiranyl)-but-2-en-1-ol. The product was prepared by General Procedure K using using di(1-methyl-ethylene)zinc (73 mg, $0.5 \mathrm{mmol})$, $1.5 \mathrm{~mL}(1.5 \mathrm{mmol}, 1.0 \mathrm{M}$ in hexanes$)$ diethylzinc, $9.6 \mathrm{mg}(0.04 \mathrm{mmol})$ (-)-MIB, $234.5 \mathrm{mg}, 1 \mathrm{~mL}(1.0 \mathrm{mmol}, 1.0 \mathrm{M}$ in hexanes) 4-(tert-butyl-diphenylsilanyloxy)-but-2-enal, and $200 \mu \mathrm{L}(0.20 \mathrm{mmol}, 1.0 \mathrm{M}$ in hexanes $) \operatorname{Ti}\left(\mathrm{O}^{i} \mathrm{Pr}\right)_{4}$. The crude product was purified by column chromatography on silica (10\% ethyl acetate in hexanes) to afford the title compound as a colorless oil in $80 \%$ yield $(306 \mathrm{mg}, 0.80 \mathrm{mmol}) .[\alpha]_{\mathrm{D}}{ }^{20}$ $=-0.047\left(c=4.3, \mathrm{CHCl}_{3}\right) ;{ }^{1} \mathrm{H} \mathrm{NMR}\left(\mathrm{CDCl}_{3}, 500 \mathrm{MHz}\right) \delta 1.05(\mathrm{~s}, 9 \mathrm{H}), 1.23(\mathrm{~s}, 3 \mathrm{H}) 2.87$ (br s, 1H), $2.88(\mathrm{~s}, 2 \mathrm{H}), 4.26(\mathrm{~d}, 1 \mathrm{H}, J=13.0 \mathrm{~Hz}), 4.35(\mathrm{~d}, 2 \mathrm{H}, J=14.0 \mathrm{~Hz}), 5.45(\mathrm{dt}, 1 \mathrm{H}$, $J=6.0,14.0 \mathrm{~Hz}), 5.95(\mathrm{~m}, 1 \mathrm{H}), 7.43(\mathrm{~m}, 5 \mathrm{H})$, and $7.70(\mathrm{~m}, 5 \mathrm{H}) \mathrm{ppm} ;{ }^{13} \mathrm{C}\left\{{ }^{1} \mathrm{H}\right\} \mathrm{NMR}$ $\left(\mathrm{CDCl}_{3}, 125 \mathrm{MHz}\right) \delta 17.8,19.1,26.8,50.2,58.7,60.4,68.8,127.7,128.4,129.9,133.9$, 134.8, and 135.5 ppm; IR (neat) 3340, 2927, 1594, 1260, and $1006 \mathrm{~cm}^{-1}$; HRMS-ESI $\mathrm{m} / \mathrm{z}$ $405.1870\left[(\mathrm{M}+\mathrm{Na})^{+}\right.$; calcd for $\left.\mathrm{C}_{23} \mathrm{H}_{30} \mathrm{O}_{3} \mathrm{NaSi}: 405.1862\right]$. 


\section{Conditions for the Determination of Enantiomeric Excess}

The enantiomeric excess values for the following epoxy alcohols were determined by chiral HPLC analysis using a Chiralcel OD-H column. The conditions for the resolution of the racemates are described below.

(Table 3, Entry 5) 1-(7-Oxa-bicyclo[4.1.0]hept-1-yl)-3-trityloxy-prop-2-en-1-ol. $t_{1}=$ $7.6 \mathrm{~min}, \mathrm{t}_{2}=13.2 \mathrm{~min}$ (hexanes/2-propanol: $95 / 5,0.5 \mathrm{~mL} / \mathrm{min}$ ).

(Table 3, Entry 6) 1-(2-Methyl-3-phenyl-oxiranyl)-hept-2-en-1ol. $\mathrm{t}_{1}=5.9 \mathrm{~min}, \mathrm{t}_{2}=$ $6.6 \mathrm{~min}$ (hexanes/2-propanol: 95/5, $0.5 \mathrm{~mL} / \mathrm{min}$ ).

(Table 4, Entry 7) 4-(Isopropyl-diphenyl-silanyloxy)-1-(2-methyl-oxiranyl)-but-2-en1-ol. $\mathrm{t}_{1}=16.4 \mathrm{~min}, \mathrm{t}_{2}=18.4 \mathrm{~min}$ (hexanes $/ 2$-propanol: $97 / 3,1.0 \mathrm{~mL} / \mathrm{min}$ ).

The enantiomeric excess values for the following epoxy alcohols were determined by chiral capillary GC analysis using a Supleco $\beta$-Dex 120 fused silica column (30 m x 0.25 $\mathrm{mm} \times 0.25 \mu \mathrm{m}$ film thickness). The carrier gas was nitrogen; inlet temperature was 250 ${ }^{\circ} \mathrm{C}$; FID detector at $270{ }^{\circ} \mathrm{C}$. The conditions for the resolution of the racemates are described below.

(Table 3, Entry 1) 7-Chloro-1-(7-oxa-bicyclo[4.1.0]hept-1-yl)-hept-2-en-1-ol. $\quad t_{1}=$ $53.4 \mathrm{~min}, \mathrm{t}_{2}=65.0 \mathrm{~min}\left(100{ }^{\circ} \mathrm{C}, 1.0 \mathrm{~mL} / \mathrm{min}\right)$.

(Table 3, Entry 2) 1-(3,3-Dimethyl-oxiranyl)-4,4-dimethyl-pent-2-en-1-ol. $t_{1}=47.2$ $\min , \mathrm{t}_{2}=53.1 \mathrm{~min}\left(100{ }^{\circ} \mathrm{C}, 1.0 \mathrm{~mL} / \mathrm{min}\right)$.

(Table 3, Entry 3) 4,4-Dimethyl-1-(7-oxa-bicyclo[4.1.0]hept-1-yl)-pent-2-en-1-ol. $\mathrm{t}_{1}=$ $100.2 \mathrm{~min}, \mathrm{t}_{2}=113.4 \mathrm{~min}\left(120^{\circ} \mathrm{C}, 1.0 \mathrm{~mL} / \mathrm{min}\right)$.

(Table 3, Entry 4) 1-(7-Oxa-bicyclo[4.1.0]hept-1-yl)-hept-2-en-1-ol. $t_{1}=9.1 \mathrm{~min}, \mathrm{t}_{2}=$ $19.2 \mathrm{~min}\left(100{ }^{\circ} \mathrm{C}, 1.0 \mathrm{~mL} / \mathrm{min}\right)$.

(Table 4, Entry 1) 3-Methyl-1-(6-oxa-bicyclo[3.1.0]hex-1-yl)-but-2-en-1-ol. $\mathrm{t}_{1}=277.4$ $\min , \mathrm{t}_{2}=284.0 \mathrm{~min}\left(90{ }^{\circ} \mathrm{C}, 0.5 \mathrm{~mL} / \mathrm{min}\right)$.

(Table 4, Entry 2) 2-Methyl-1-(7-oxa-bicyclo[4.1.0]hept-1-yl)-prop-2-en-1-ol. $t_{1}=$ $18.4 \mathrm{~min}, \mathrm{t}_{2}=20.5 \mathrm{~min}\left(110^{\circ} \mathrm{C}, 1.0 \mathrm{~mL} / \mathrm{min}\right)$.

(Table 4, Entry 3) 1-(3,3,-Dimethyl-oxiranyl)-2-methyl-prop-2-en-1-ol. . $\mathrm{t}_{1}=6.2 \mathrm{~min}$, $\mathrm{t}_{2}=16.6 \mathrm{~min}\left(110{ }^{\circ} \mathrm{C}, 1.0 \mathrm{~mL} / \mathrm{min}\right)$.

(Table 4, Entry 4) 3-Methyl-1-(6-oxa-bicyclo[3.1.0]hex-1-yl)-but-2-en-1-ol. $t_{1}=$ 103.8 min, $\mathrm{t}_{2}=108.9 \min \left(130{ }^{\circ} \mathrm{C}, 1.0 \mathrm{~mL} / \mathrm{min}\right)$. 
(Table 4, Entry 5) 1-(3,3-Dimethyl-oxiranyl)-oct-2-yn-1-ol. $t_{1}=75.8$ min, $t_{2}=82.0$ $\min \left(130{ }^{\circ} \mathrm{C}, 1.0 \mathrm{~mL} / \mathrm{min}\right)$.

(Table 4, Entry 6) 1-(2-Methyl-oxiranyl)-oct-2-yn-1-ol. $t_{1}=17.9 \mathrm{~min}, \mathrm{t}_{2}=26.0 \mathrm{~min}$ $\left(100{ }^{\circ} \mathrm{C}, 1.0 \mathrm{~mL} / \mathrm{min}\right)$. 


\section{${ }^{1} \mathrm{H}$ and ${ }^{13} \mathrm{C}\left\{{ }^{1} \mathrm{H}\right\}$ NMR Spectra}
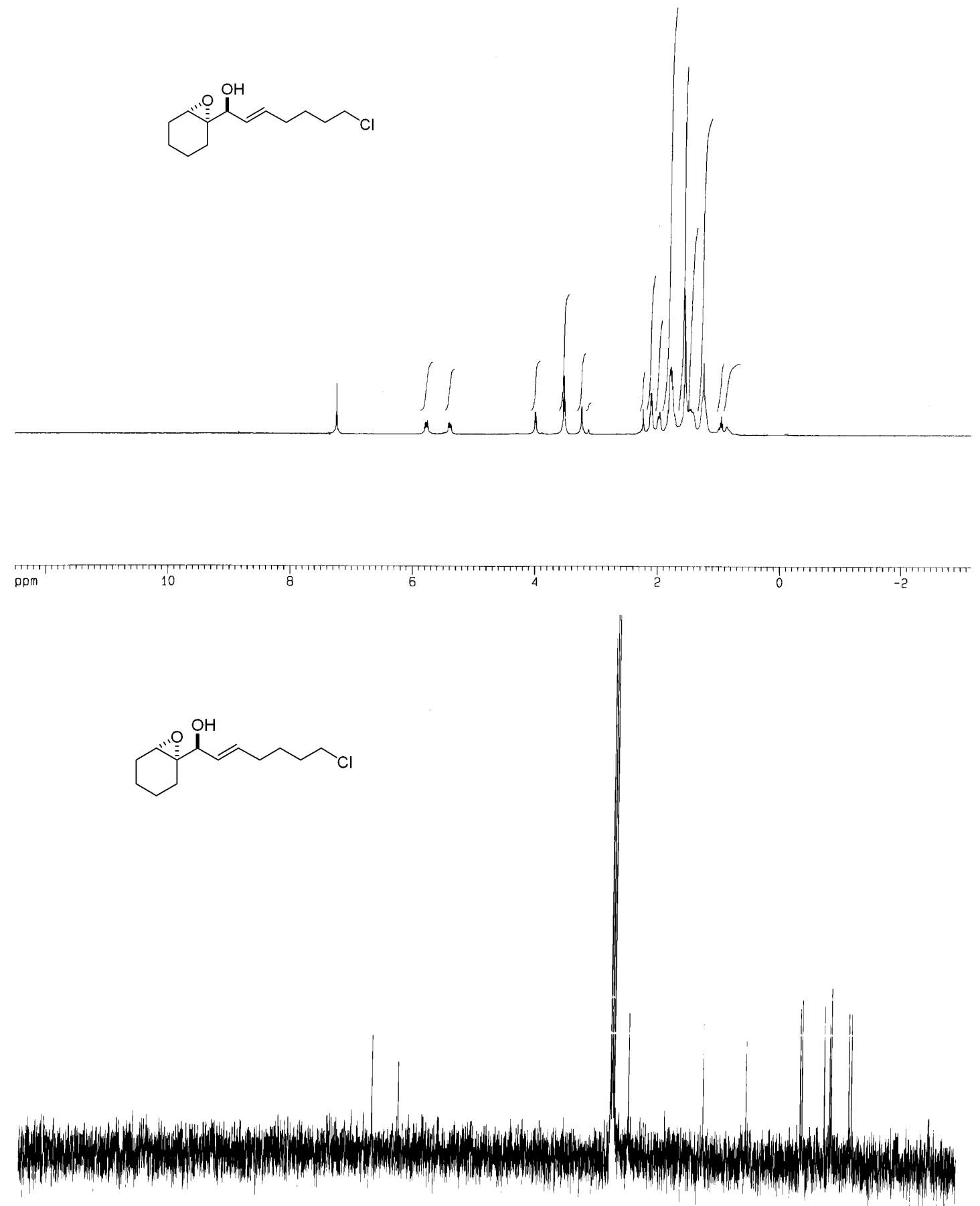
S21
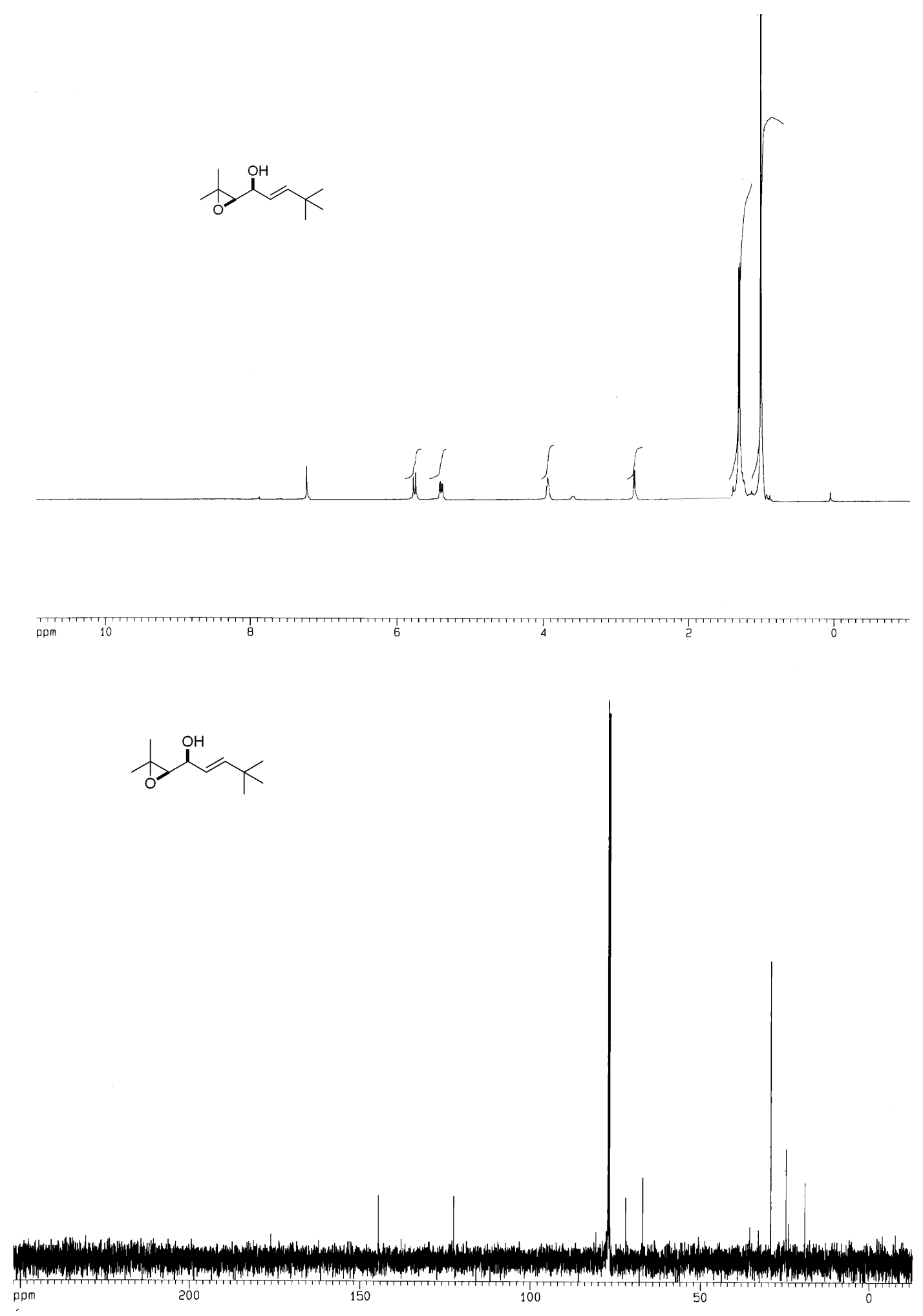
S22

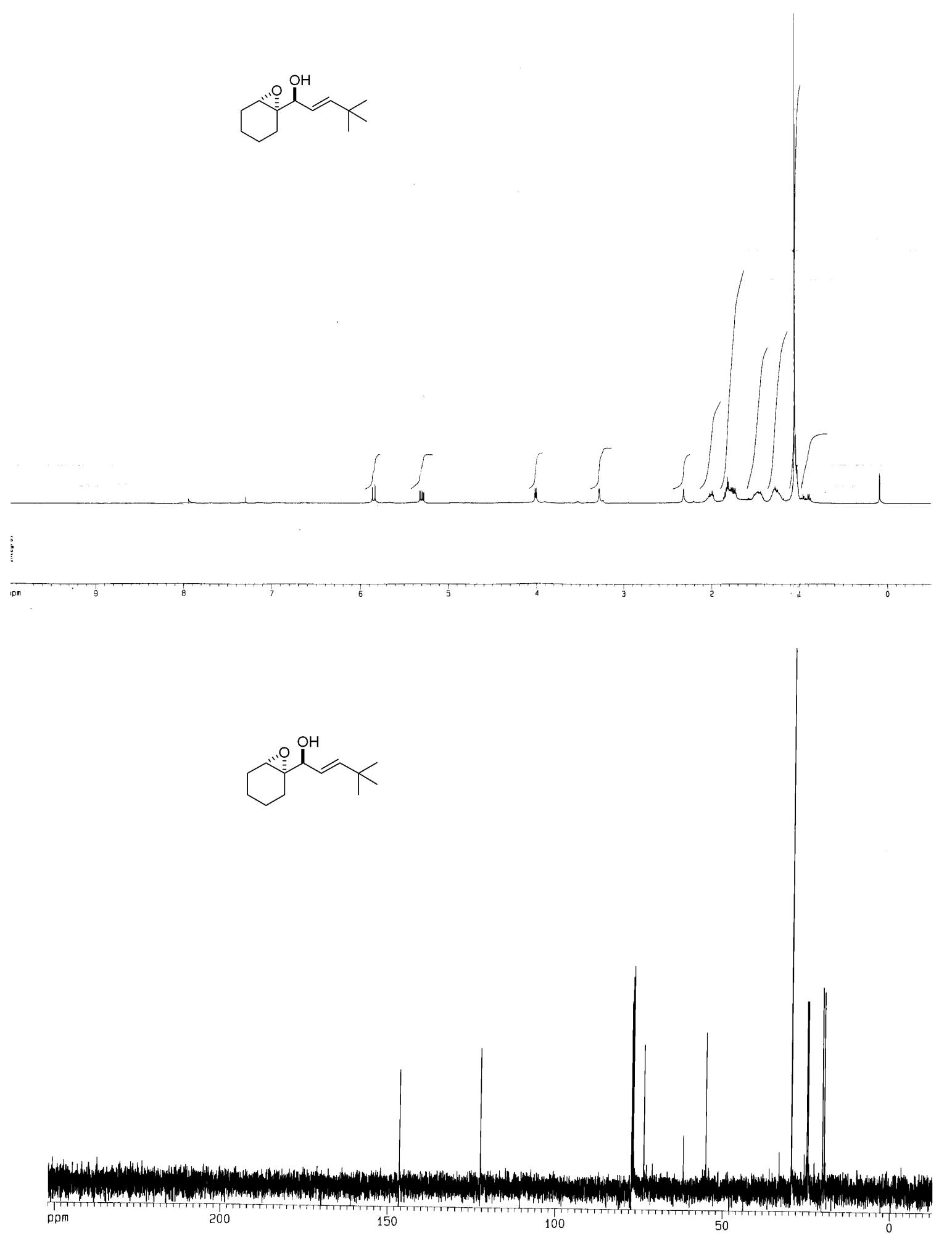



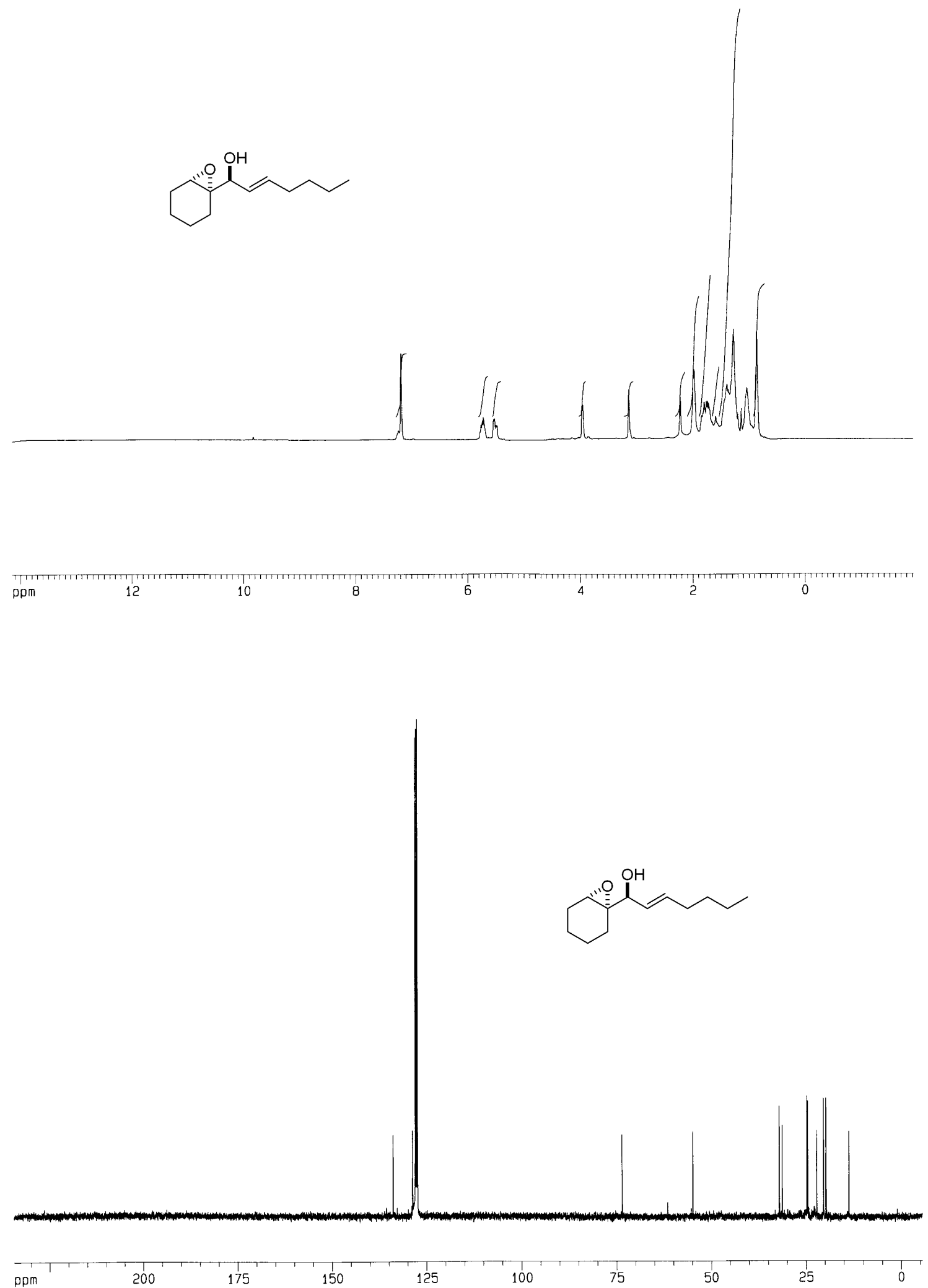
S24

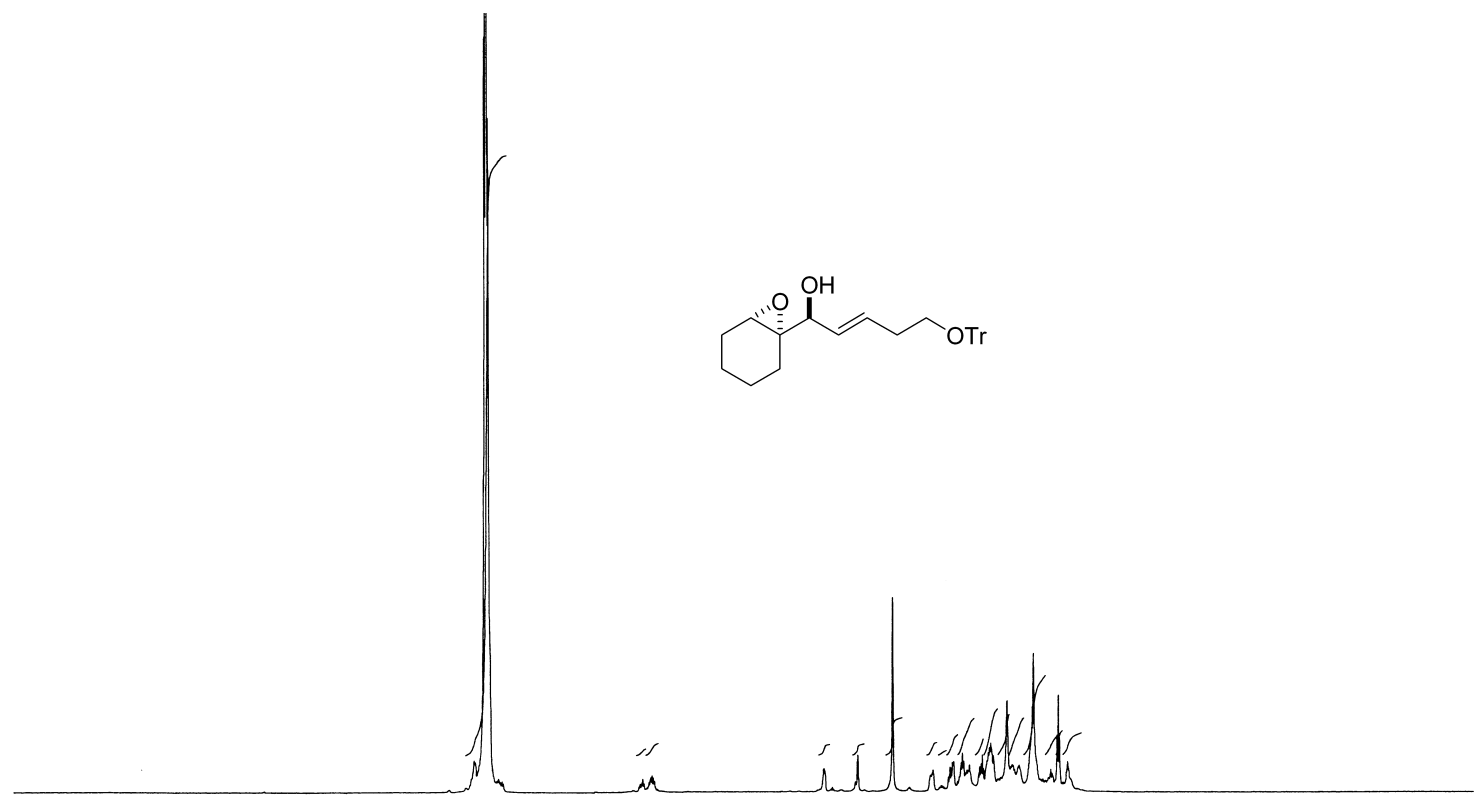

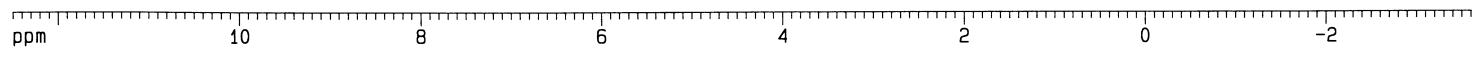
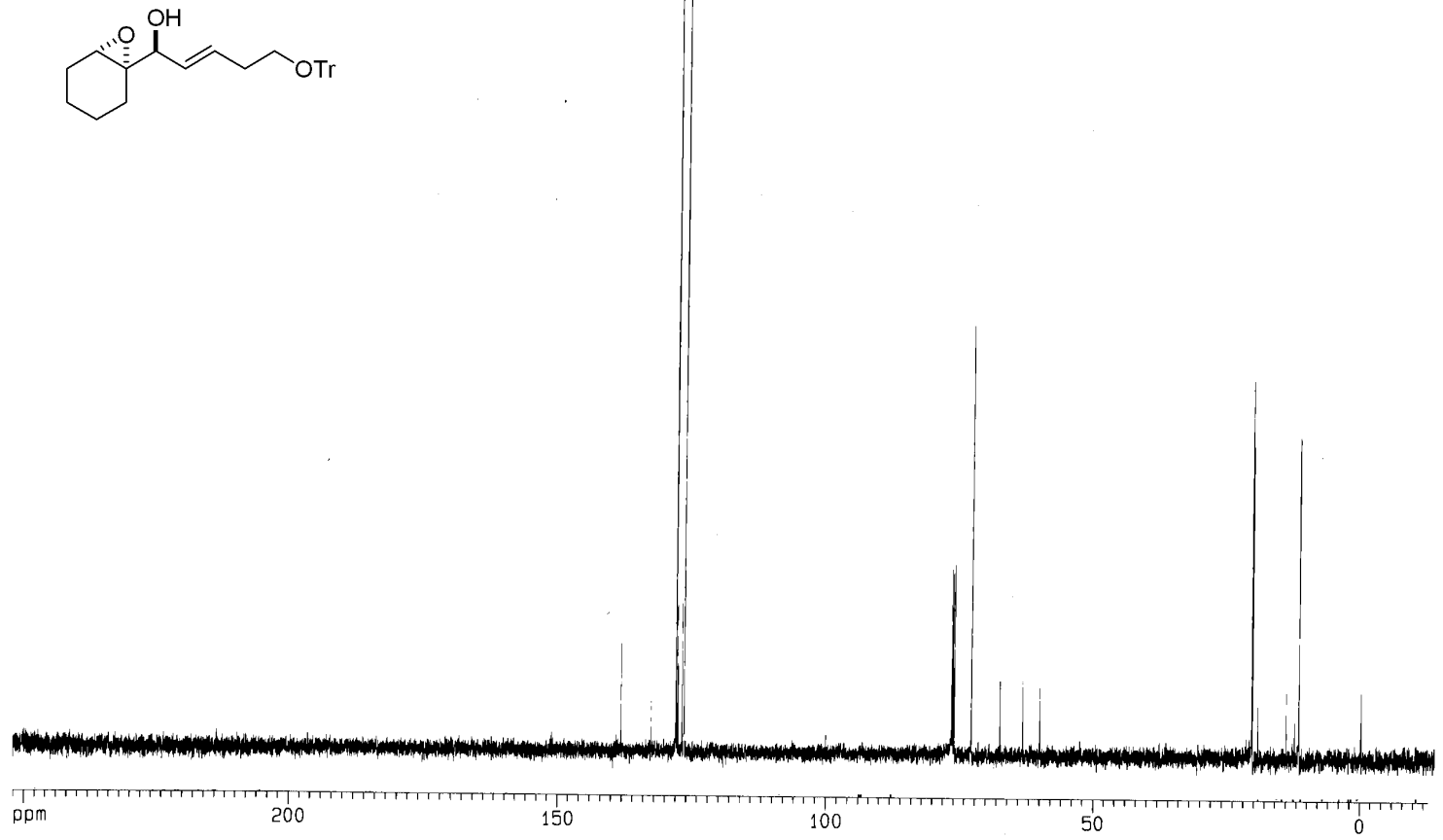


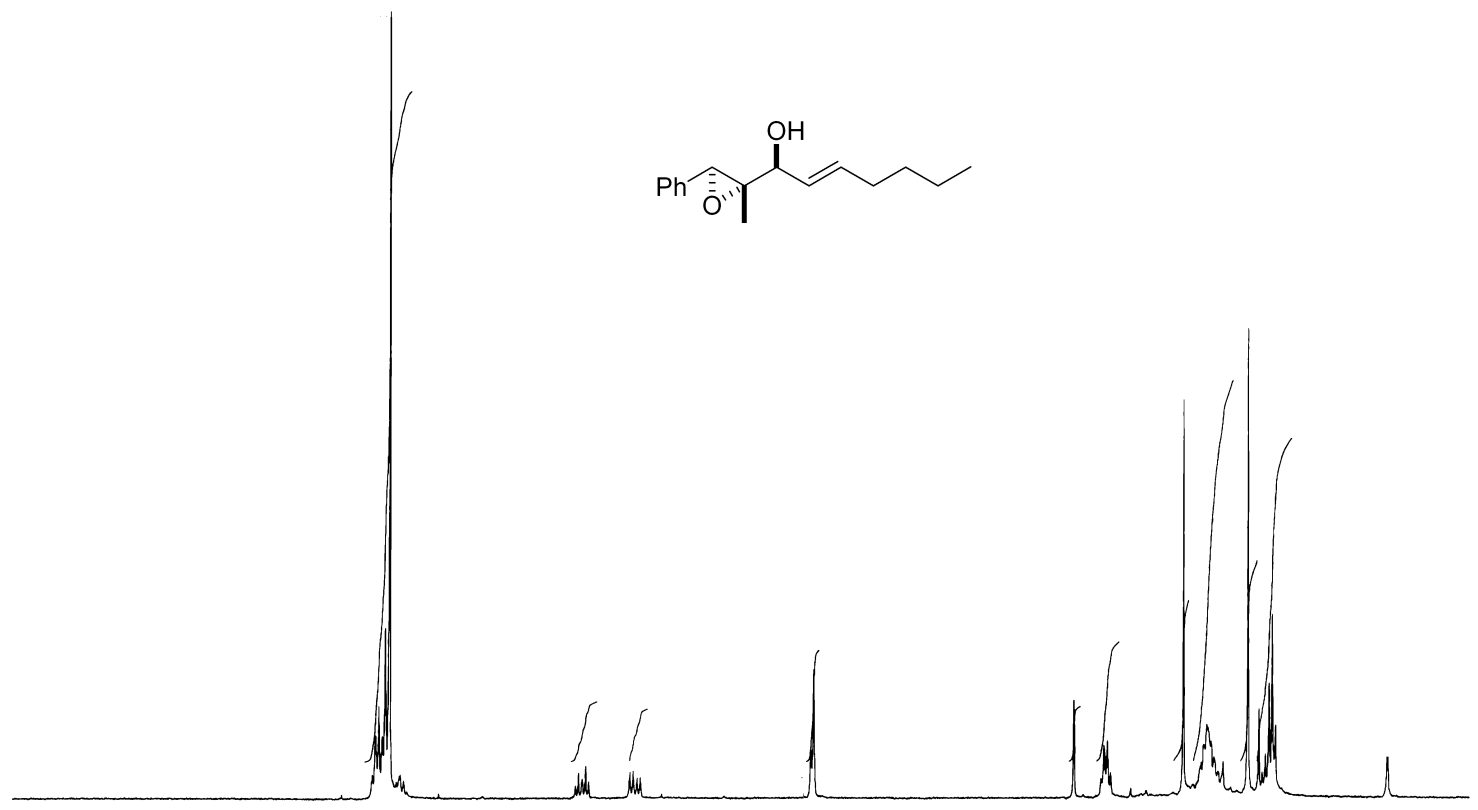<smiles>CCCCCC=CC(O)C(C)C(C)(C)Cc1ccccc1</smiles>

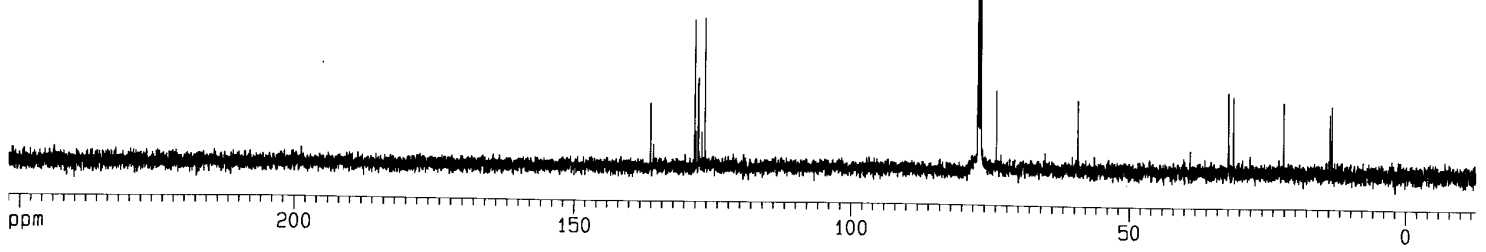


S26

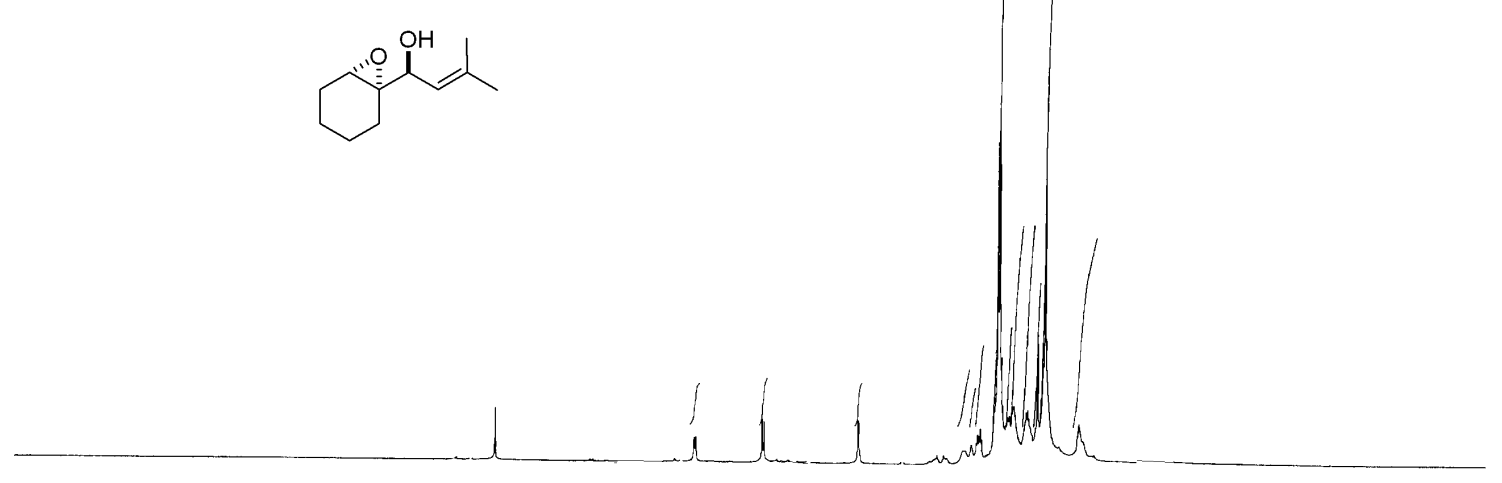

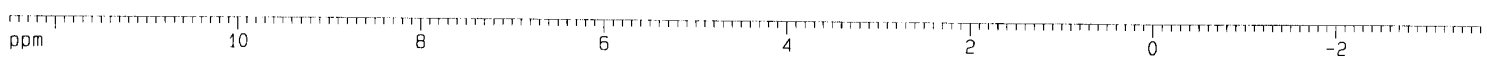

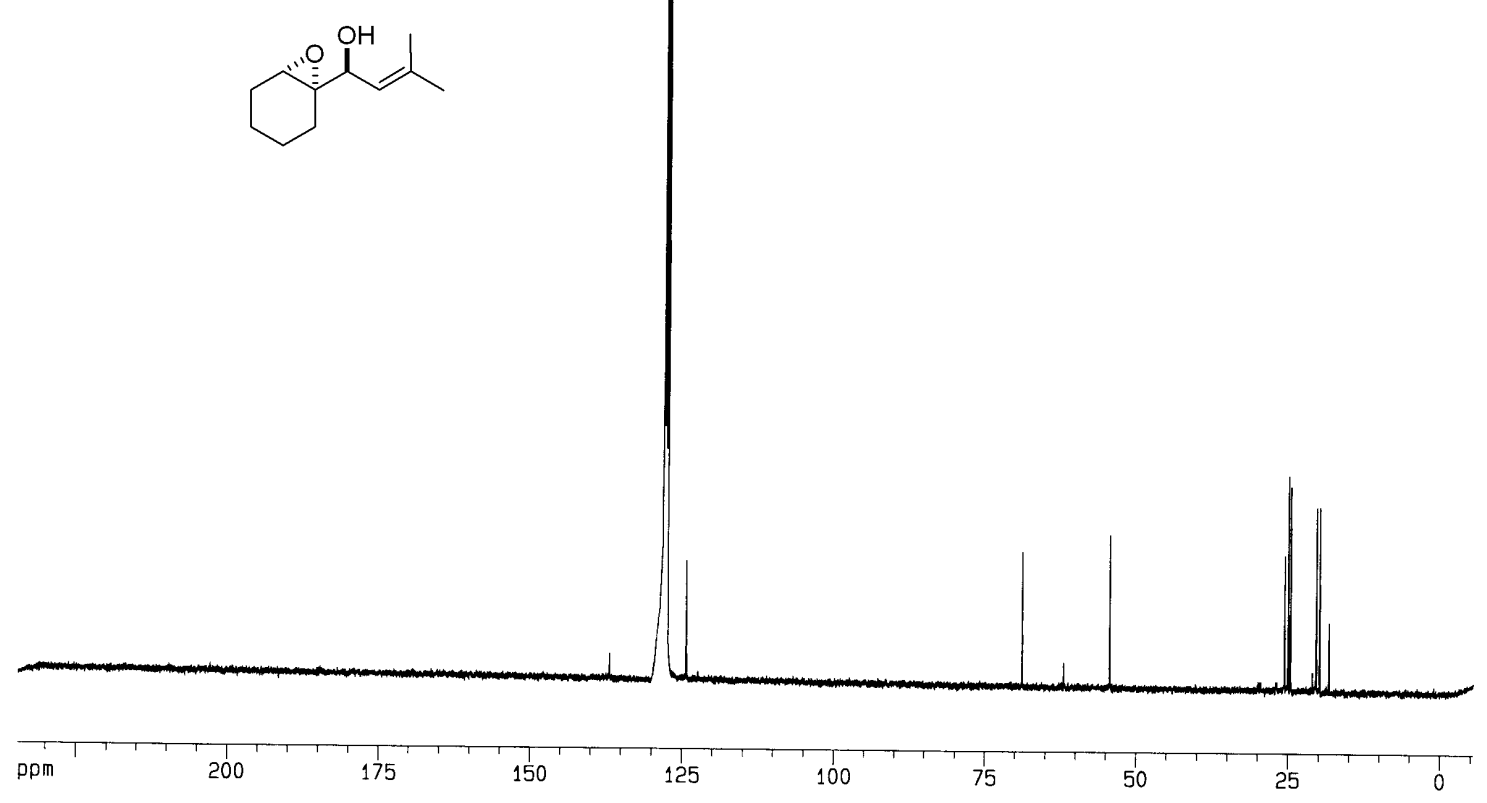



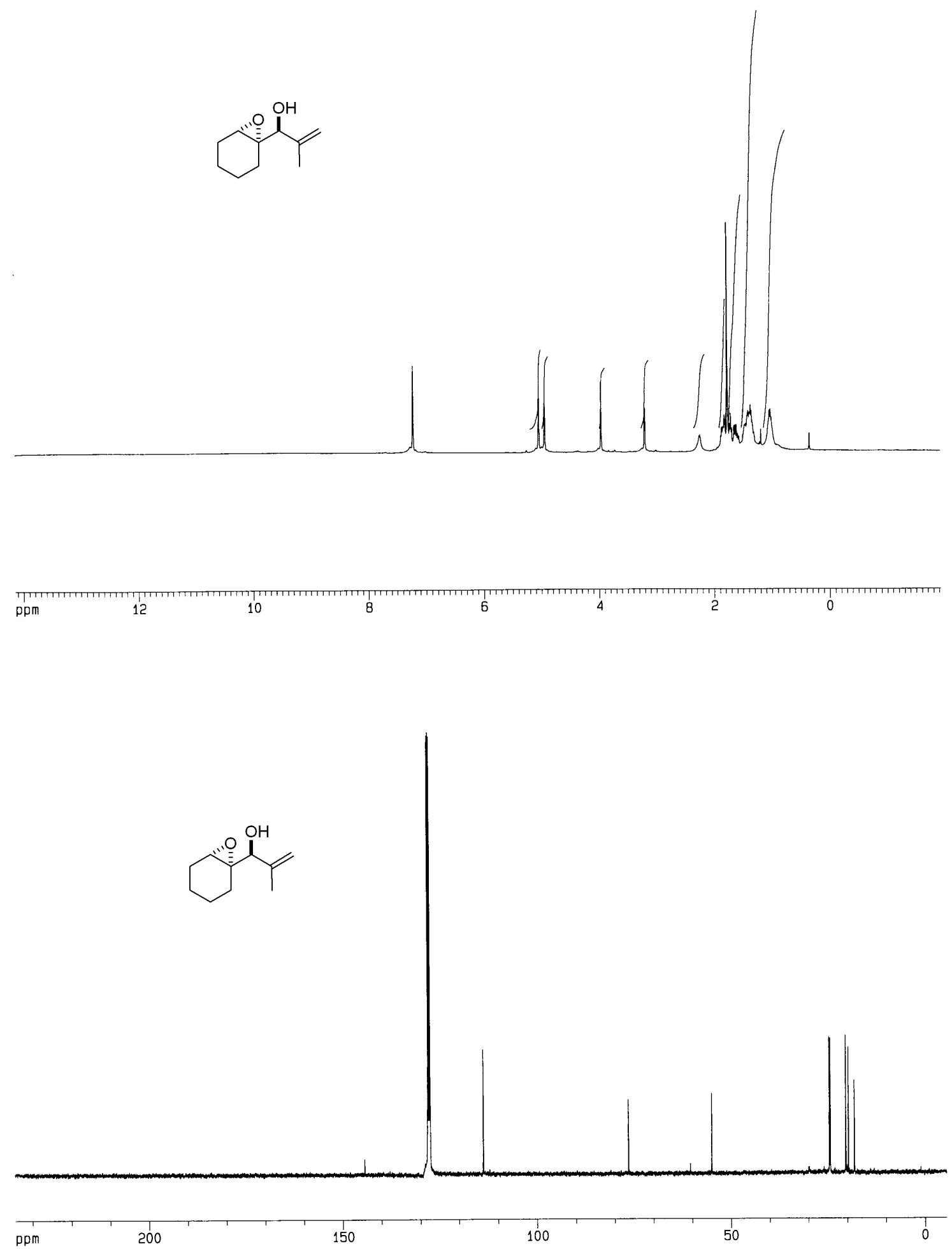
S28

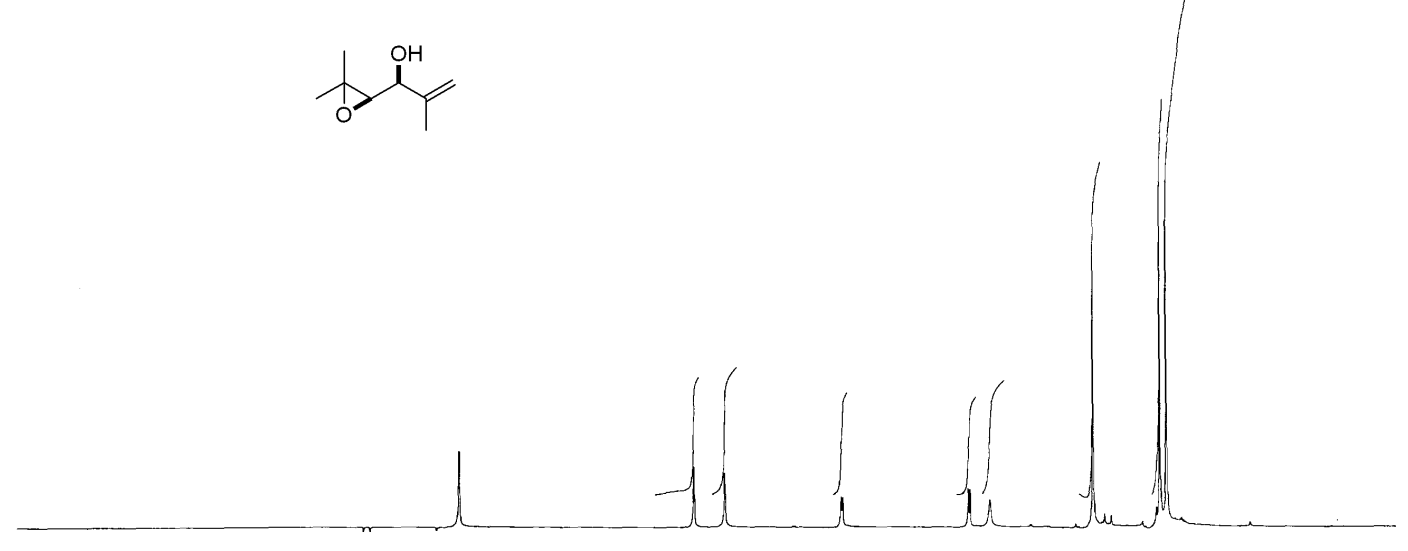

$\operatorname{ppm}{ }_{10}$

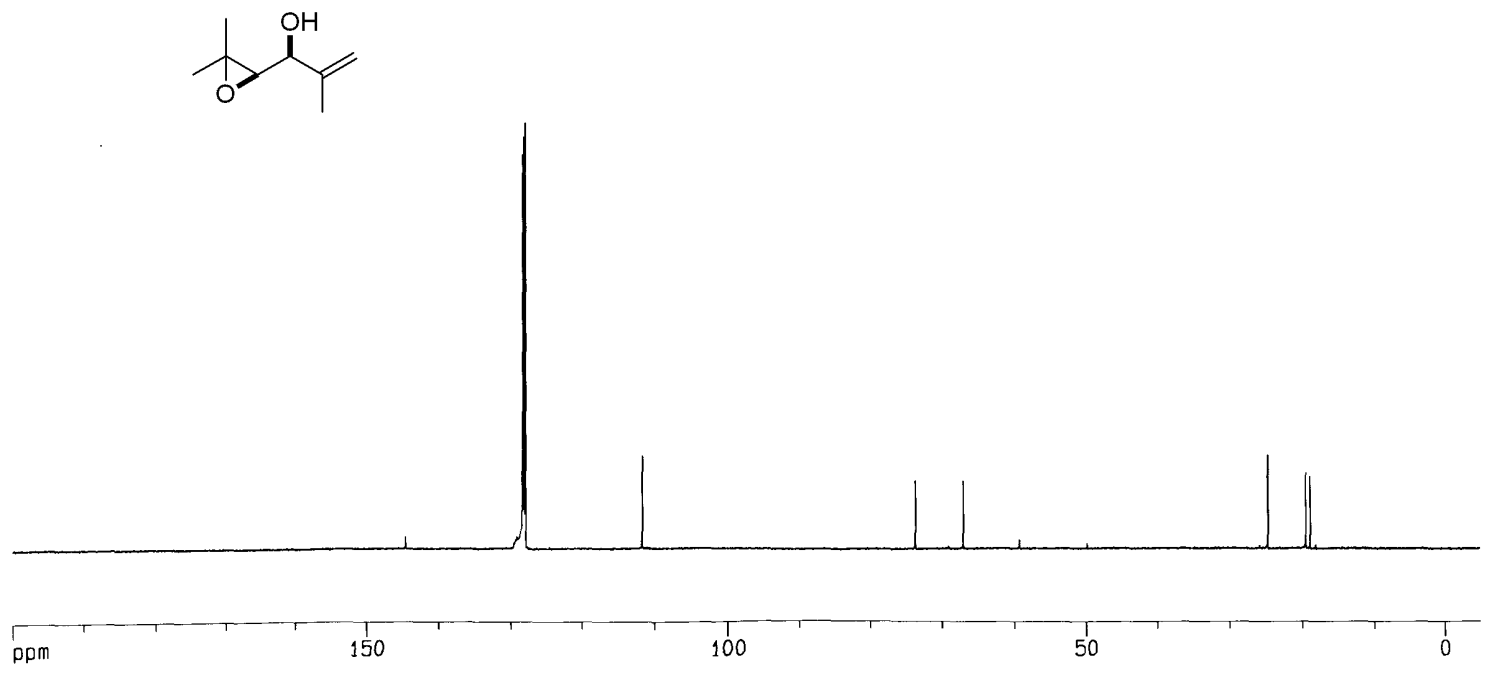



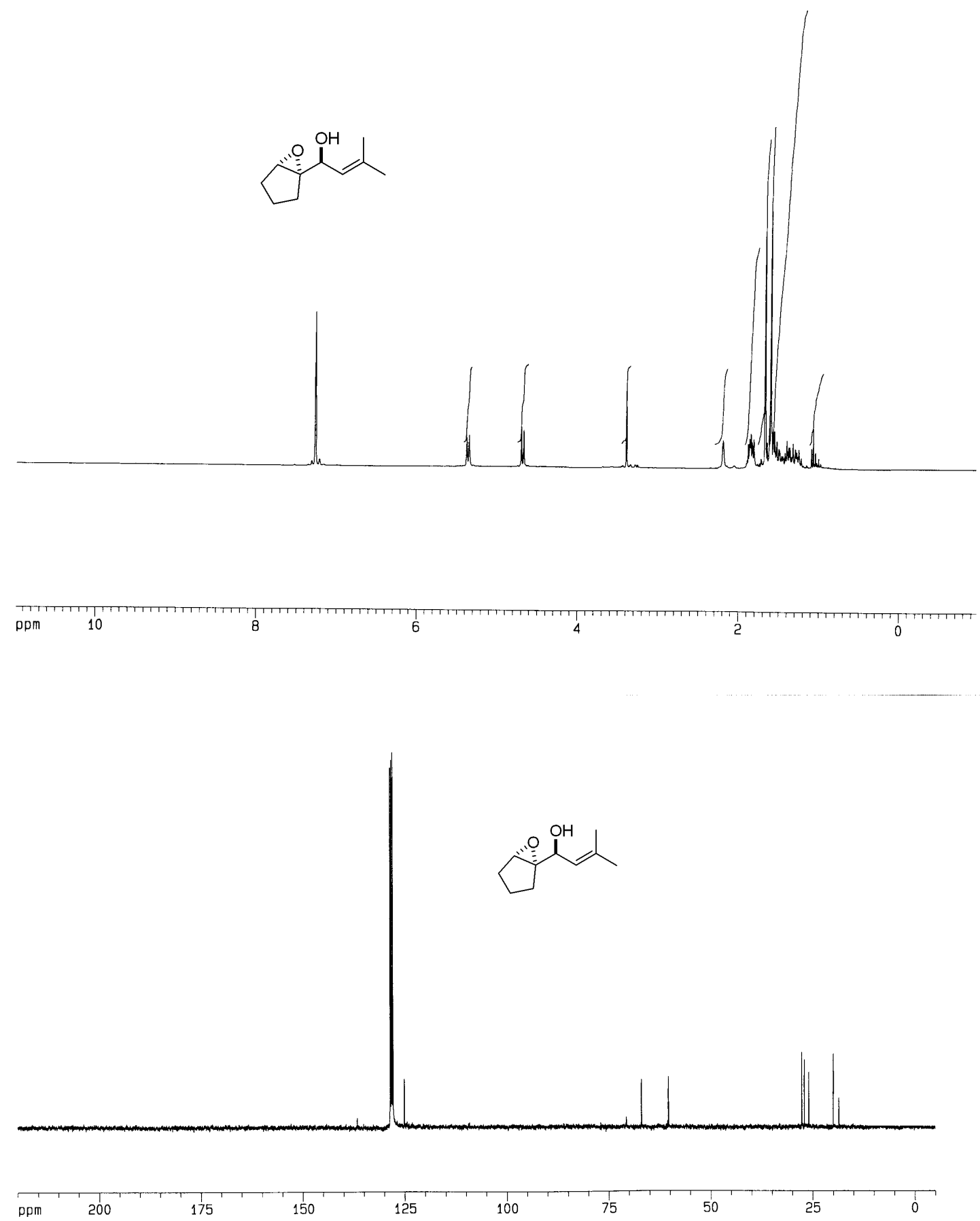

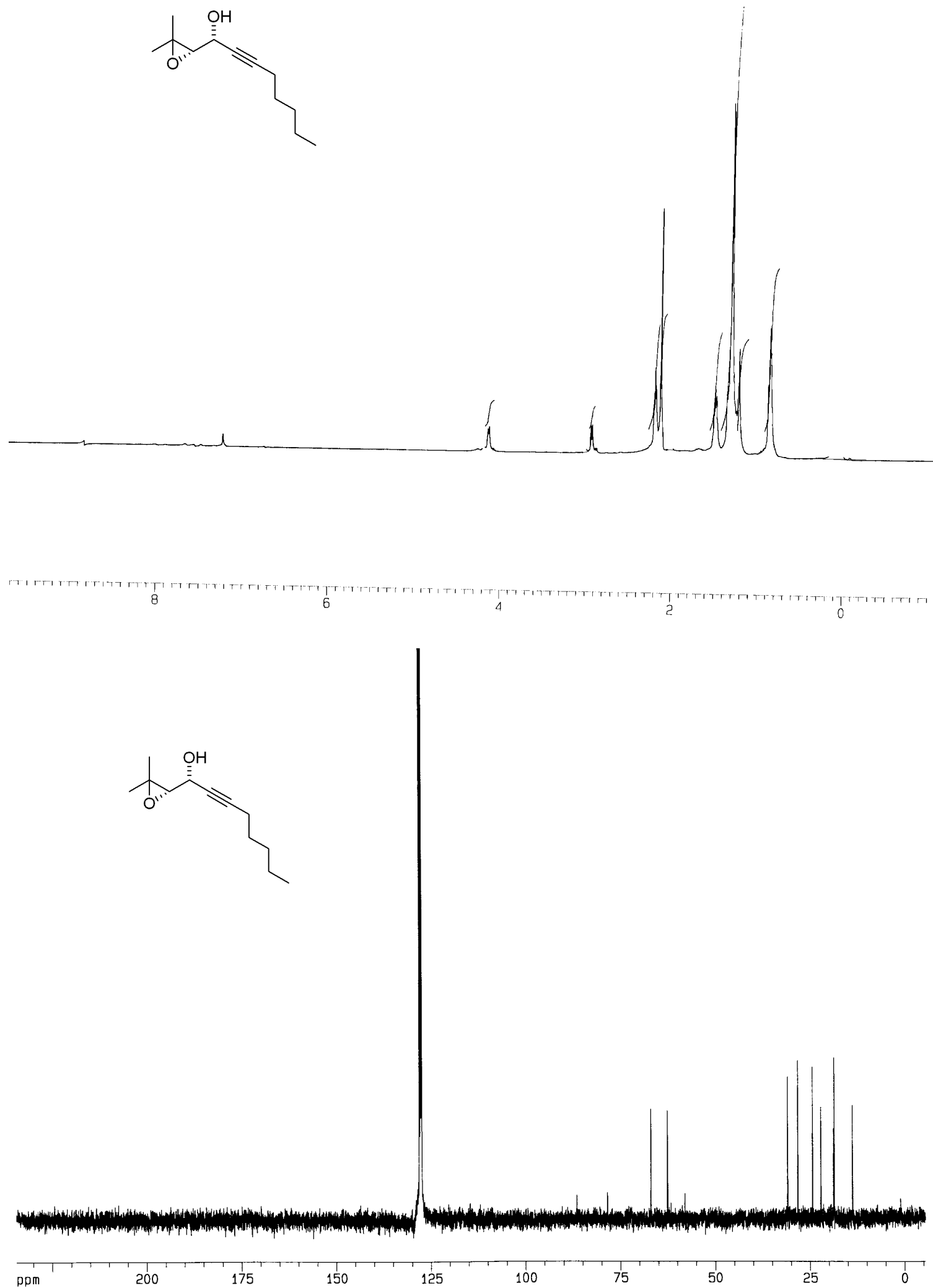

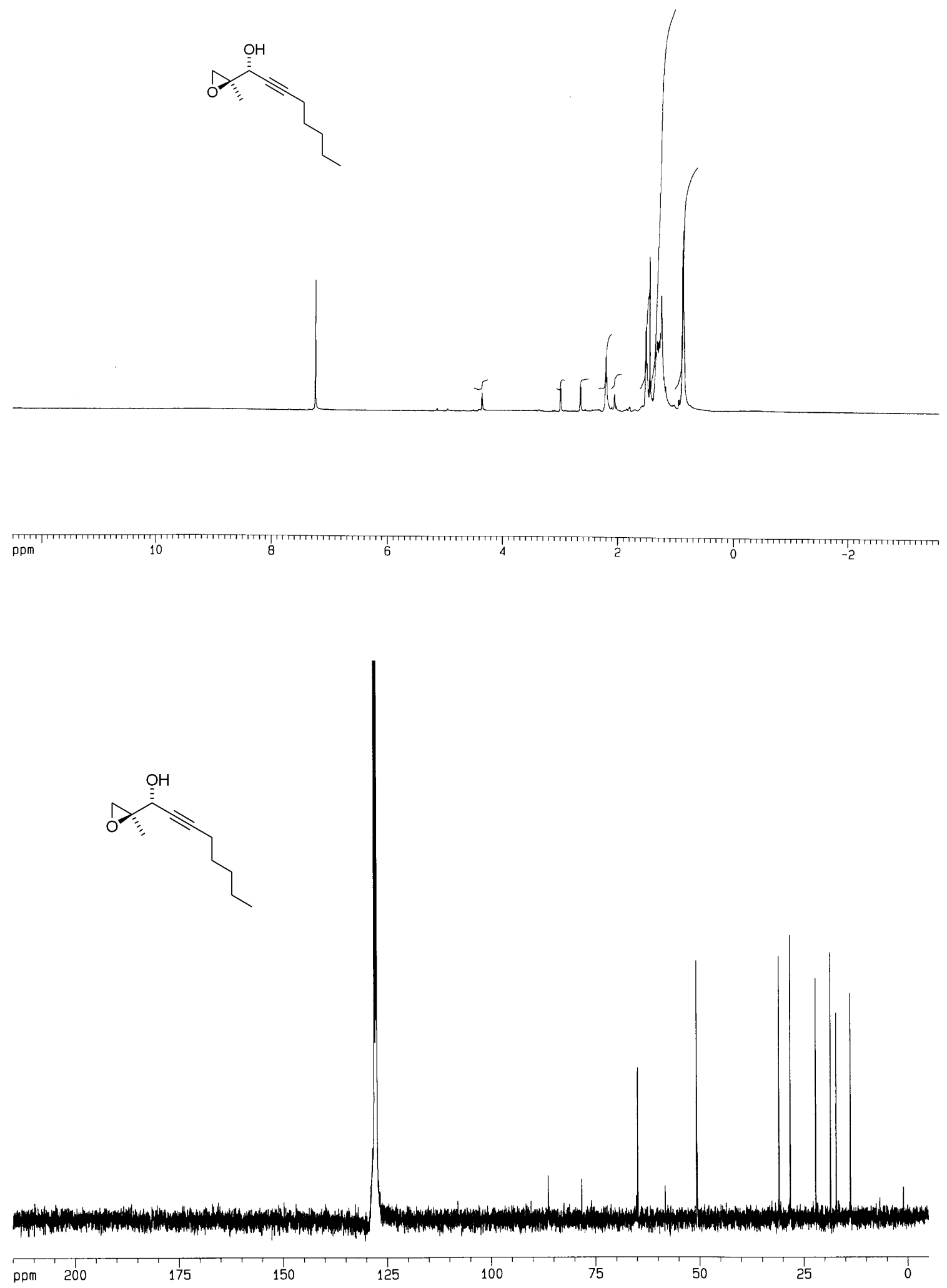

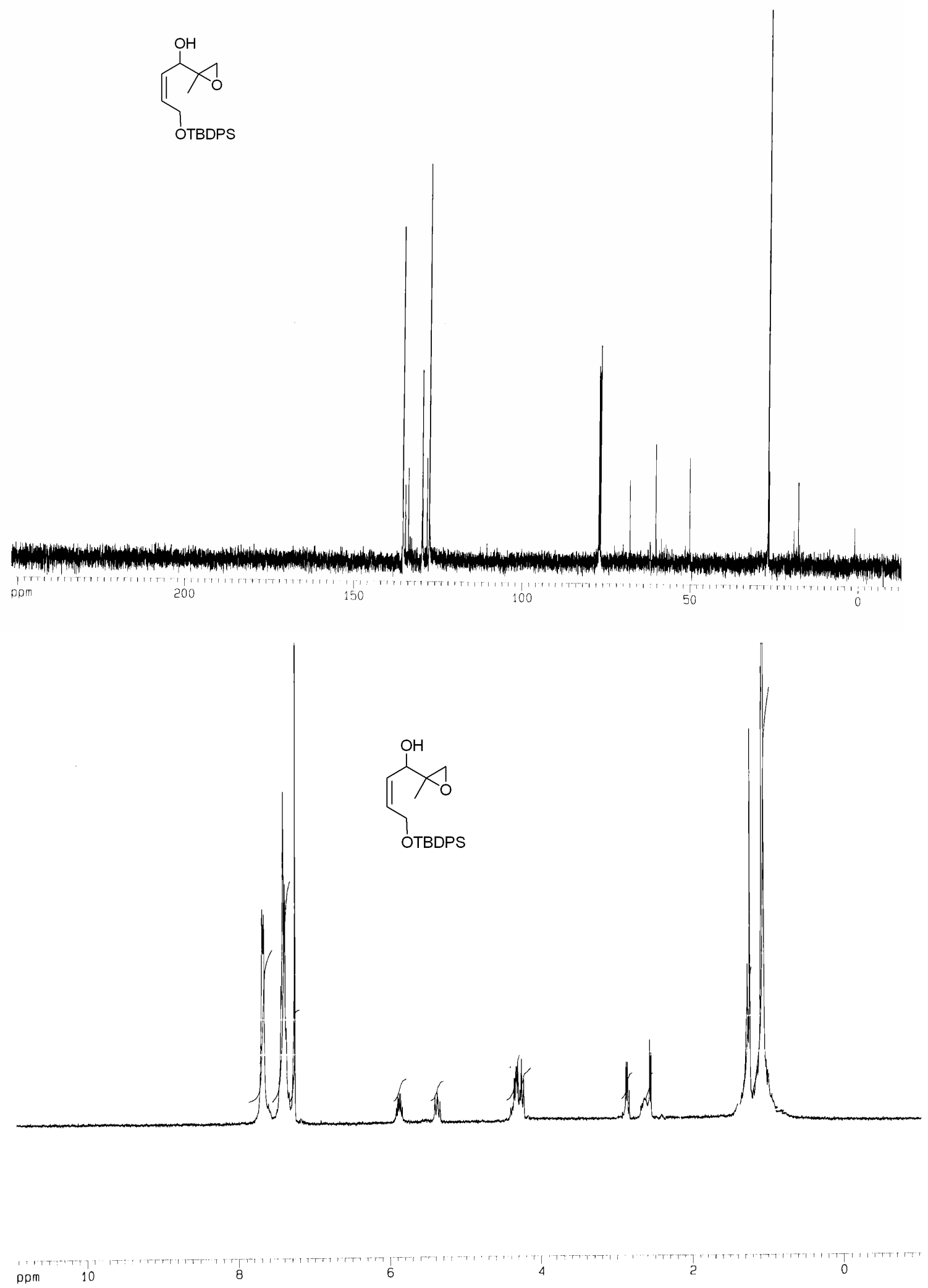


\section{References}

(1)Gao, Y.; Hanson, R. M.; Klunder, J. M.; Ko, S. Y.; Masamune, H.; Sharpless, K. B. J. Am. Chem. Soc. 1987, 109, 5765-5780.

(2)Lurain, A. E.; Maestri, A.; Rowley Kelly, A.; Walsh, P. J. J. Am. Chem. Soc. 2004, 126, 13608-13609.

(3)Wang, Z.-M.; Zhou, W.-S. Tetrahedron 1987, 43, 2935-2944. 